\title{
Capital Controls and Foreign Exchange Policy
}

\author{
Marcel Fratzscher \\ European Central Bank
}

The question of whether capital controls should be part of the tool box for policymakers to deal with capital flows has become one of the central issues in the international economic policy debate. It was one of the key policy issues in the G20 under the French Presidency in 2011, and it has been covered extensively by the International Monetary Fund (IMF) and other international institutions and fora. However, despite a G20 commitment to arrive at "coherent conclusions" on capital flow management, only limited progress has been made so far.

One reason for the slow progress is that few policy issues have been as controversial as the desirability of capital controls. One side of the debate argues that financial liberalization and integration are a key foundation for global prosperity and growth, with capital mobility and access to foreign capital being an important source for investment and the diversification of risk. In contrast, policymakers of some emerging market economies emphasize the risks stemming from unfettered capital flows for the macroeconomic and financial stability objectives of their countries.

An analysis of all these arguments in favor and against capital controls reveals four overarching motives for the use of capital controls have emerged in the recent policy debate: a foreign exchange policy objective; a capital flow management goal; a financial stability aim; and a macroeconomic policy objective. First, authorities may pursue capital controls with a foreign exchange policy objective in mind, that is, to maintain a stable exchange rate that is not overvalued and thus does not impinge on the competitiveness of the domestic economy. Critics of capital

I am grateful to Norman Loayza, my discussant, and conference participants for comments and discussions, and Bogdan Bogdanov for excellent help with the data preparation. Views expressed in this paper are those of the author and do not necessarily reflect those of the European Central Bank.

Capital Mobility and Monetary Policy, edited by Miguel Fuentes D., Claudio E. Raddatz, and Carmen M. Reinhart, Santiago, Chile. (C) 2014 Central Bank of Chile. 
controls and those pointing to the presence of "competitive devaluations" have gone a step further, arguing that capital controls have in some cases been actively used to achieve or maintain undervalued exchange rates. Second, policymakers' goal in pursuing capital controls may be related to capital flows, that is, to reduce both the volume and volatility of capital flows and to lower the share of relatively more risky portfolio flows. A third objective discussed in the policy debate is that of financial stability: policymakers may maintain or implement capital controls in order to shield the domestic economy and financial institutions from volatile capital flows and to avoid an overheating and overreliance on foreign capital. Under the fourth objective, capital controls may reflect a country's concerns about the real economy (namely, growth, growth volatility, inflation or public debt) or external vulnerability (that is, the current account or external debt).

This paper tests the empirical validity of these four hypotheses. Which of these four objectives is the primary motive for capital controls? The paper starts by identifying the characteristics of countries with high levels of capital controls and the ways in which these countries differ from those with free capital mobility. The paper uses a broad set of macroeconomic and financial variables, covering a broad set of 79 economies over the period 1984-2009, to gauge which of the four hypotheses are most important for understanding which countries maintain a high level of financial restrictions and which have few restrictions.

In the second step of the analysis, the paper then tries to explain the factors that cause policymakers to actively change the level of capital controls. Which of the four hypotheses best explains why some policymakers impose or raise capital controls and why others reduce them?

The third element of the analysis is based on an event study that investigates the evolution of macroeconomic and financial variables around changes in capital controls, including increases as well as reductions. How are countries that raise controls different from those that lower them or keep them unchanged? What is the experience of countries in the years after they change their capital controls relative to others?

Addressing these questions is challenging, partly because of the complexity of the various factors that may induce policy actions and partly due to methodological difficulties in identifying causes and effects. The paper takes a different approach from much of the literature that focuses on the effects or effectiveness of capital 
controls. The main goal of the present paper is not to analyze the effects of controls, but to identify which motives induce policymakers to adopt them in the first place; irrespective of whether they are then successful in achieving their objectives. This more modest objective also averts some of the difficult issues related to identification and, in particular, to endogeneity of the introduction of capital controls. The capital control measures employed are those developed by Chinn and Ito $(2008,2011)$ and Schindler (2009), which are proxies for the de jure financial openness of countries.

Overall, the empirical findings of the paper suggest that a foreign exchange policy objective has been an important, if not dominant, motive of capital controls globally. Countries with higher levels of capital controls tend to have undervalued (real effective) exchange rates. The undervaluation of the exchange rate is the single most important variable explaining a larger share of the difference in the level of capital controls across countries than any other variable in the analysis. Moreover, countries with undervalued exchange rates are more likely to raise existing capital controls further, especially since 1999. The event study analysis suggests that the degree of undervaluation increases in the years following large rises in capital controls. In addition, countries with high exchange rate volatility not only tend to have significantly higher levels of capital controls, but also are more likely to raise controls.

Another important dimension of the link between capital controls and foreign exchange policy relates to the country's exchange rate regime and monetary policy regime. Reducing the volatility and magnitude of capital flows through administrative controls makes it considerably easier for a central bank to maintain a fixed exchange rate regime. Conversely, countries with a flexible currency regime and an inflation-targeting monetary policy regime are less likely to need capital controls to achieve their policy objectives. The findings of the empirical analysis are consistent with this argument, as countries with flexible exchange rate regimes and those with an inflation-targeting regime tend to be more open financially. Moreover, since 1999 countries with inflation-targeting regimes have much more frequently reduced existing capital controls than nontargeting countries.

By contrast, there is no compelling evidence in the data that either the level of or changes in capital flows per se are an important motive for capital controls: countries with larger capital flows- measured relative to the overall size of countries' economies-are those that have more open capital accounts. Moreover, countries that have raised 
capital controls in the past have tended to have a comparatively lower level and volatility of capital flows. This evidence is corroborated by the event study, which shows that net portfolio flows decline in the years following significant increases in capital controls.

The evidence also uncovers only a mixed link between financial stability objectives and the level and changes in capital controls. Countries with deeper financial markets have a lower level of capital controls and are also less likely to raise capital controls. Moreover, countries with more financial stress (in bond, equity and money markets) in prior years tend to have lower levels of controls and are more likely to liberalize their capital account in subsequent years.

By contrast, countries with high growth rates in credit to the private sector are significantly more likely to raise capital controls. This variable on credit growth turns out to be one of three most important variables accounting for cross-country differences in capital controls. Moreover, countries with high inflation and volatile growth of gross domestic product (GDP) are also more likely to raise capital controls. Taken together, this suggests that concerns about an overheating economy, rather than purely about the financial market or asset prices, guide the decisions of policymakers to raise capital controls.

Many of these empirical links are either only present since 1999 or are particularly strong in that period, consistent with the argument that the 1997-98 Asian crisis may have induced a fundamental change in policymakers' objectives, in particular with regard to exchange rate policy.

In sum, the findings of the paper suggest that a foreign exchange policy objective and concerns about an overheating of the domestic economy have been the two main motives for capital flow management over the past two decades, especially in the 2000s. Both the level of capital controls the likelihood of raising existing controls further are strongly associated with fixed exchange rate regimes and significantly undervalued exchange rates. As to the financial stability side, the evidence suggests that capital controls are motivated not by worries about financial market volatility, but rather by concerns about capital inflows triggering or contributing to an overheating of the economy, in the form of high credit growth, rising inflation and output volatility. Finally, the paper also uncovers evidence that capital controls have externalities across countries, as governments are more likely to raise controls when other countries in the region have done so recently.

These findings have a number of policy implications. A first important point is that capital control measures seem to be used 
not in a purely defensive manner when it comes to foreign exchange policy: the presence and introduction of capital controls are not merely associated with avoiding an appreciation or overvaluation of the domestic currency, but rather are linked to a significant undervaluation of the exchange rate. This suggests that policymakers' concerns about competitive devaluations and currency wars, which have become so prominent in recent years, may not be unfounded. The competitive motive behind capital controls is strengthened by the finding that countries are more likely to raise controls when neighbouring countries have recently done so, as well.

Second, the evidence is consistent with the argument that capital flow management policies are used to compensate for the absence of autonomous macroeconomic and financial policies and effective adjustment mechanisms. The fact that countries with a high level of capital controls, as well as those actively implementing controls, tend to have fixed exchange rate regimes, a non-inflation-targeting monetary policy regime, and shallow financial markets indicates that policymakers need to use capital controls to protect their economies against capital flows. Although the size of the capital flows is rather modest relative to the overall size of the economy in countries with higher capital controls, their effect on the domestic economy (in terms of credit growth, inflation and output volatility) tends to be large when policy tools than other capital controls are absent and when financial markets are not deep enough to absorb those flows.

The fact that countries with high capital controls exhibit a worse performance with regard to credit growth, inflation and output volatility-and introducing (additional) controls does not seem to lower these overheating pressures systematically in subsequent years-makes it very hard to see capital control measures as a firstbest policy option. Instead, financial market development and the creation of policy frameworks that allow for autonomous and credible macroeconomic and prudential policies may constitute a superior path to shield the domestic economy from fickle capital flows. While some consider capital flow management policies to be appropriate temporary measures to buy time for policymakers to enact more fundamental macroeconomic and prudential reforms, such policies carry the risk not only of creating domestic and international distortions, but reducing incentives for policymakers to pursue deeper reforms. The persistence or frequent re-introduction of capital control measures suggests that this risk may not be unfounded.

Several caveats have to be emphasized. Most importantly, one needs to be very cautious in interpreting the relationships identified 
here as establishing a causal link. Not only are countries with different levels of capital controls different in a multitude of ways, but the introduction of capital controls is never a random event and may be triggered by factors not covered by the analysis. This paper attempts to avoid these pitfalls by focusing not on assessing the effects or effectiveness of capital controls, but rather on analyzing and identifying differences in factors in the past, which are linked to policymakers' decisions to maintain or change capital controls today.

The paper proceeds by outlining the main arguments of both supporters and critics of capital controls in the current policy debate and reviewing some of the underlying academic literature, in section 1 . Section 2 then describes the empirical methodology and the data used for the empirical analysis. Section 3 outlines the four main hypotheses to be tested and discusses the empirical findings. The final section summarizes the findings and draws policy implications.

\section{The Pros and Cons of Capital Controls}

Much of the recent policy debate has focused on the circumstances in which capital controls may constitute a useful policy tool. ${ }^{1}$ This issue has become so important because of the experience of emerging market economies with capital flows during and after the 2007-08 financial crisis. The sudden collapse of capital inflows and the marked capital flight in the second half of 2008, and the subsequent influx in 2009 and 2010, put a lot of strain on domestic economies and financial markets in many emerging economies. ${ }^{2}$

A helpful framework for considering the issue is in terms of market distortions and market failures: if markets work efficiently, capital is allocated optimally, and any control on capital flows implies

1. The IMF has conducted substantial work in recent years on the issue of capital controls and their role in the policy mix, in particular in emerging markets. For a clear outline of the state of the debate and some underlying evidence, see Ostry and others (2010, 2011) and Chamon and others (2011).

2. A rapidly growing literature discusses various elements of this experience, including the drivers of capital flow cycles (that is, sudden stops, reversals, surges and retrenchments) and the 2007-08 crisis and its implications (see Forbes and Warnock, 2011; Aizenman and Sushko, 2011; Cowan and De Gregorio, 2007; Cowan and others, 2008; Calvo, Izquierdo and Mejía, 2011; Raddatz and Schmukler, 2011; and Fratzscher, 2011). There is also a growing literature linking capital flows to contagion and the cross-border transmission of shocks (see, for example, Broner, Gelos and Reinhart, 2006; Bekaert and others, 2011). 
a distortion. Hence, much of the policy discussion about the potential role of capital controls has concentrated on the question of under which market failures are capital controls welfare improving.

A first type of distortion is related to international market failures. For instance, many ermerging market policymakers have argued that excessively loose monetary policy in the United States and other advanced economies since 2009 has been pushing more capital into emerging economies than warranted by underlying economic fundamentals. Other international distortions or market failures may relate to contagion and herd behavior of international investors, which can trigger excessive, temporary capital flows into some emerging economies. Capital controls may thus reduce the adverse effects of such distortions on the domestic economies receiving excessively large capital inflows. In short, capital controls may play a useful policy role if capital flows are excessive, temporary and primarily due to push factors, that is, factors that lie outside the control of domestic policy makers.

The second type of distortion or market failure that can be addressed through capital controls are domestic in nature. The most frequently emphasized domestic distortions frequently have a macroprudential and microprudential origin: capital flows may exacerbate existing financial fragilities in economies that are particularly vulnerable, that is, which have less financial development and depth and weaker institutions for dealing with financial stability issues. Other domestic fragilities may relate to the balance sheets of domestic firms and households, which may be adversely affected by large fluctuations in capital flows.

Based on the perspectives of both types of distortions, several policymakers have argued that capital controls may thus be seen as a macroprudential policy tool as much as a macroeconomic policy tool. Capital controls may become an even more important policy tool when other policies are constrained or not available at all. In particular, using an exchange rate appreciation as a buffer against a capital inflow surge is less feasible if the exchange rate is already overvalued and if the economy lacks competitiveness. Similarly, using foreign exchange interventions to absorb inflows is less desirable if foreign exchange reserves are already high and exceed what is needed for purely precautionary motives. ${ }^{3}$

3. For a discussion and evidence on the link between capital controls and exchange rate policy, see Jeanne (2011). 
The desirability of using capital controls to deal with capital flow fluctuations may also depend on the space of monetary policy and fiscal policy. For instance, lowering interest rates to discourage capital inflows may not be a feasible policy option in an economy that has high inflation and is concerned about overheating. Tightening fiscal policy to reduce demand and counteract a surge in capital inflows may not be an option if fiscal policy is already tight and public debt high.

In a nutshell, this has been the general reasoning of many proponents of capital controls as a policy tool in the current debate. In contrast, critics tend to point out that in many cases capital controls are not a first-best solution, but rather an inferior alternative to needed policy reforms that address the financial stability risks from capital flow fluctuations, such as improving macro- and microprudential supervision and regulation; deepening financial markets; improving institutions; reforming macroeconomic policy frameworks (in particular with regard to monetary policy, fiscal policy and exchange rate regimes); and moving toward flexible exchange rate regimes to obtain fully autonomous monetary and fiscal policies.

In addition to being inferior policy responses, the imposition and maintenance of capital controls may in fact delay those needed reforms, with substantial longer-term costs to the domestic economy. Moreover, there is a huge literature investigating whether capital controls have been effective at all in dealing with capital flow fluctuations. ${ }^{4}$ The findings in the literature do not yield compelling evidence in favor of the effectiveness of capital controls, although a consensus is emerging that while capital controls are easily circumvented and thus may not have a substantial effect on volume, they appear to change the composition of capital flows toward less risky and less volatile types of flows.

There is also compelling evidence that the capital controls imposed by individual economies can have adverse externalities and consequences for the global economy, which has triggered calls for closer cooperation of capital flow management policies at the global level, in particular through the G20 process. One such externality occurs through exchange rate management: if capital controls are used to maintain or induce undervalued exchange rates,

4. For an overview of this literature and its findings, see the excellent surveys of Magud, Reinhart and Rogoff (2011), Forbes (2007), Cardarelli, Elekdag and Kose (2009) and, for the 1980s and early 1990s, Calvo, Leiderman and Reinhart (1996). Henry (2007) provides a review of the broader experience with capital account liberalization. 
it lowers the competitiveness of that country's trading partners. In fact, following the 2007-08 financial crisis, there has been a heated debated about some emerging economies engaging in competitive devaluations-or currency wars as Brazilian Finance Minister Guido Mantega called it-due to countries using foreign exchange interventions and capital controls to weaken their currencies. The massive increase in foreign exchange reserve holdings and the widespread introduction of capital controls by emerging economies are consistent with this argument.

Another externality is that the imposition of controls in one country may make it politically more attractive for other countries to adopt similar controls, thus leading to serious impediments to financial globalization. ${ }^{5}$ Finally, the introduction of capital controls may divert capital flows to other countries. For instance, there is evidence that the introduction and raising of capital controls on portfolio inflows by Brazil in 2008-11 caused a significant diversion effect that increased capital inflows into other Latin American economies and other emerging economies outside Latin America. ${ }^{6}$ Such externalities can be particularly strong for small emerging markets when the economy imposing controls is as large as Brazil. Overall, this case highlights the importance of pursuing and adopting a coordinated approach to capital controls.

\section{Methodology ANd Data}

This section starts by outlining the empirical approach for testing the four overarching potential motives for the use of capital controls, as stressed by the recent policy debate and outlined above: a foreign exchange policy objective; a capital flow management goal; a financial stability aim; and a macroeconomic policy objective. The main intention is to identify the factors that distinguish countries according to their choice of capital controls, in terms of both the overall level of de jure restrictions

5. See Prasad and others (2003) for a compelling overview of the arguments and underlying evidence on financial globalization. Many other benefits from financial globalization have been analyzed in the literature, in particular with regard to the diversification of risk and for investment; see Curcuru and others (2011), Hau and Rey (2005), Gelos and Wei (2005) and Rajan (2010).

6 . Forbes and others (2012). Korinek (2010) provides a conceptual presentation of externalities and capital flows. 
maintained by a country and the decision to either raise or lower existing controls. To identify the vector of factors $\mathbf{X}_{i, t}$ of country $i$ that relate to the level of capital controls $(C C)$, the benchmark model to be estimated is formulated as

$C C_{i, t}=\alpha_{t}+\mu \mathbf{X}_{i, t-1}+\varepsilon_{i, t}$

while the benchmark model to relate factors to the choice of changes in capital controls is

$D_{i, t}^{C C}=\alpha_{t}+\lambda \mathbf{X}_{i, t-1}+\varepsilon_{i, t}$

$D_{i, t}$ is a dummy variable equal to one if a country raises capital controls in year $t$ and zero if it keeps existing controls unchanged. In a second model specification, the estimation is conducted for cases when capital controls are lowered, so that $D_{i, t}$ equals one if a country lowers capital controls in year $t$ and zero if existing controls are unchanged. Equation (1) is estimated via ordinary least squares (OLS); equation (2) uses a logit specification. ${ }^{7}$

Moreover, three types of models are estimated. In a first step, each individual factor $\mathbf{X}_{\mathrm{i}, \mathrm{t}}$ is included separately (I call these the individual models); in a second step, all factors of a particular hypothesis are included together (the combined model); and in a third step, an encompassing procedure reduces the model specification in a stepwise fashion so as to arrive at the model that includes only those factors that are statistically significant at least at the 20 percent level (the encompassing model).

Both equations (1) and (2) include time effects $\alpha_{t}$ to take into account the general, common time trend in capital controls, whereby capital controls generally decrease over time. The inclusion of time dummies in equation (2) is less obvious, yet it turns out that the (re-) introduction of capital controls is clustered in a few particular years

7. In alternative specifications, equation (1) is estimated allowing for censoring at the lower bound, as a number of observations of the dependent variable lie at the lower/zero value of the dependent variable. Results are very similar to those using a linear OLS specification. The OLS estimation is presented below because the parameter estimates are more easily interpreted. Equation (2) is alternatively estimated using a multinomial logit specification, which allows estimating both models (the one for increasing capital controls and the one for lowering controls) in a single model, yielding identical parameter estimates. 
of the sample. ${ }^{8}$ Robust standard errors are reported throughout.

An important issue is the potential endogeneity of capital controls. As discussed above, much of the literature focuses on the effect of capital controls on various macroeconomic and financial variables, which raises the concern that such effects cannot be cleanly identified since capital controls are likely to be a direct or indirect endogenous result of the very same variables. This problem does not arise here because the analysis focuses on characterizing and identifying the factors that are associated with differences in the level and changes of capital controls. However, these factors may themselves be influenced by capital controls. I partly address this concern by analyzing past values of these factors, that is, including the lagged values of the factors $\mathbf{X}_{i, t-1}$. This does not entirely solve the problem, as both dependent and independent variables may be persistent over time; thus one needs to be careful when interpreting the parameter estimates in a causal way. ${ }^{9}$

The third part of the empirical analysis is an event study of the behavior of the factors $\mathbf{X}_{i}$ in the years before and after changes in capital controls. The motivation for this analysis is to understand whether fundamentals in countries raising capital controls in a particular year differ from fundamentals in countries that kept controls constant or lowered existing controls. The identification of countries raising, lowering and keeping constant their controls is the same as for equation (2) above. Again, the potential endogeneity of capital control policies means that the relationships identified in this event study should not be interpreted to imply causality.

The analysis is conducted for a broad set of 79 countries, using annual data for the period 1984-2009. Table 1 lists the countries included in the sample, where emerging market economies constitute about half of the countries. The sample and time period are mainly determined by data availability of the capital controls variables.

8. As one would expect, empirically the inclusion of time effects matters little in the estimation of equation (2), but is crucial for equation (1).

9 . Various approaches have been employed in the literature to deal with the endogeneity issue of capital controls, such as using instrumental-variable approaches. However, these approaches are not free of pitfalls, as it is inherently difficult to identify appropriate instruments. Another challenge relates to the nonstationarity of the dependent variable in equation (1). Various test statistics are used to check, and confirm, the stationarity of the residuals. 
Table 1. Country Sample

\begin{tabular}{|c|c|c|}
\hline \multicolumn{3}{|l|}{ Advanced } \\
\hline Australia & Greece & Portugal \\
\hline Belgium & Iceland & Spain \\
\hline Canada & Ireland & Sweden \\
\hline Denmark & Italy & Switzerland \\
\hline Finland & Japan & United Kingdom \\
\hline France & New Zealand & United States \\
\hline Germany & Norway & \\
\hline \multicolumn{3}{|l|}{ Emerging } \\
\hline Algeria & Indonesia & Romania \\
\hline Argentina & Israel & Russian Federation \\
\hline Bolivia & Korea & Singapore \\
\hline Brazil & Latvia & Slovak Republic \\
\hline Chile & Malaysia & Slovenia \\
\hline China & Malta & South Africa \\
\hline Colombia & Mexico & Thailand \\
\hline Croatia & Morocco & Tunisia \\
\hline Cyprus & Pakistan & Turkey \\
\hline Czech Republic & Paraguay & Ukraine \\
\hline Ecuador & Peru & Uruguay \\
\hline Hungary & Philippines & Venezuela, RB \\
\hline India & Poland & \\
\hline \multicolumn{3}{|l|}{ Developing } \\
\hline Armenia & Ghana & Papua New Guinea \\
\hline Burundi & Guyana & Samoa \\
\hline Congo, DR & Iran & Sierra Leone \\
\hline Costa Rica & Malawi & Solomon Islands \\
\hline Dominican Republic & Moldova & Trinidad and Tobago \\
\hline Fiji & Nicaragua & Uganda \\
\hline Gambia & Nigeria & Zambia \\
\hline
\end{tabular}

Source: Author's elaboration.

Mesuring capital controls is inherently difficult. The capital control measures by Chinn and Ito (2011) and Schindler (2009) are used here to proxy the de jure financial openness of countries. The use of de jure measures provides indications about the intentions of policymakers' intentions, rather than the actual outcome or de facto openness and integration of countries. The former proxy has 
a broader coverage and a longer time series, so it is the preferred measure in the analysis, although various robustness checks show that the empirical findings are very similar when using other proxies for de jure openness. ${ }^{10}$ Both proxies are scaled so that a higher value indicates a higher degree of capital flow restrictions. ${ }^{11}$

Figure 1 plots the evolution over time of the average degree of capital controls, as well as the standard deviation of controls across countries at any point in time. The figure shows compellingly the overall trend toward fewer controls and more liberalization, although the dispersion across countries remains significant throughout the period and even rises toward the end of the $2000 \mathrm{~s}$. This is a powerful illustration that cross-country differences in capital controls globally have never been as dispersed as they are today.

\section{Figure 1. The Evolution of Capital Controls since the $1980 \mathbf{s}^{\mathbf{a}}$}

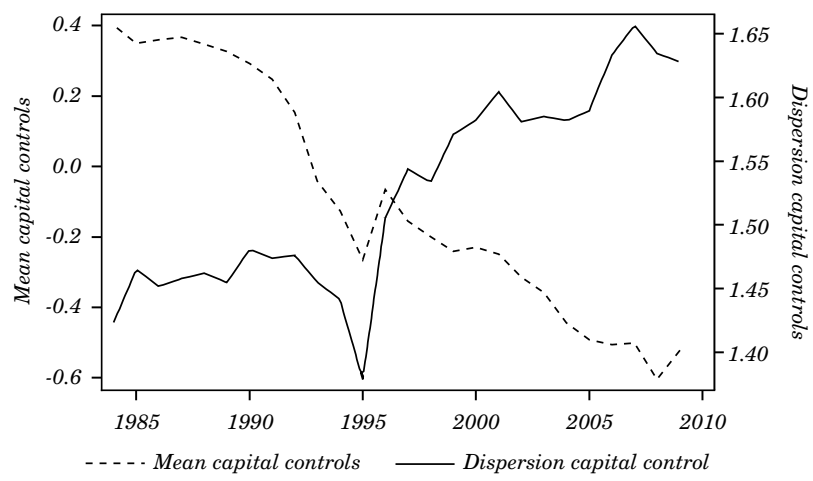

Source: Author's elaboration.

a. The figure shows the evolution of (normalized) capital controls, using the measure of Chinn and Ito (2011), for the average across all 79 countries in the sample, as well as providing the dispersion (the standard deviation across countries for each year) since 1984 .

10. There are various strengths and advantages to the measure proposed by Schindler (2009), in particular its greater detail and breakdown of individual types and categories of capital controls. The main interest for the present paper is the dimension that refers to capital account restrictions, which is used for the analysis, although this measure is highly correlated with the Chinn-Ito measure. Moreover, a feature exploited for some of the analysis here is the distinction of the Schindler proxy between restrictions on capital inflows and controls on outflows.

11. For simplicity, the paper uses the term capital controls throughout, though strictly speaking the proxies include restrictions such as on foreign exchange or current account transactions. 
Figure 2 shows the share of countries that raised capital controls, the share that lowered controls and the share that kept controls unchanged during a particular year. The figure reveals an interesting pattern, with sharp increases in capital controls occurring in many countries during the second half of the 1990s (during and following the Asian crisis) and in 2009 (after the global financial crisis of 2007-08). What is striking is that 2009 was the first year since the mid-1980s during which more countries raised capital controls than countries lowering them.

\section{Figure 2. The Evolution of Changes in Capital Controls since the $1980 \mathrm{~s}^{\mathrm{a}}$}

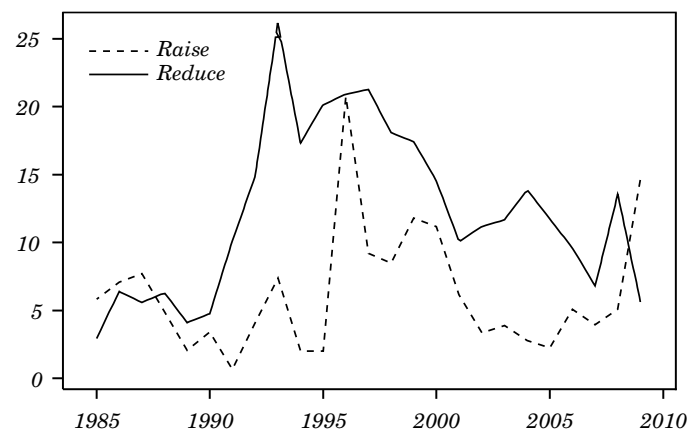

Source: Author's elaboration.

a. The figure shows the evolution of changes in (normalized) capital controls, using the measure of Chinn and Ito (2011). Specifically, the figure graphs the share of countries raising capital controls, lowering them or keeping them constant, as a share of all 79 countries in the sample for each year since 1984 .

Finally, a broad set of potential proxies is used to test the four hypotheses discussed above. Table 2 provides an overview of the definition of the variables, while table 3 gives some summary statistics. For the empirical analysis below, all factors are normalized to have a zero mean and a standard deviation of unity in order to make the parameter estimates more easily comparable across variables. 


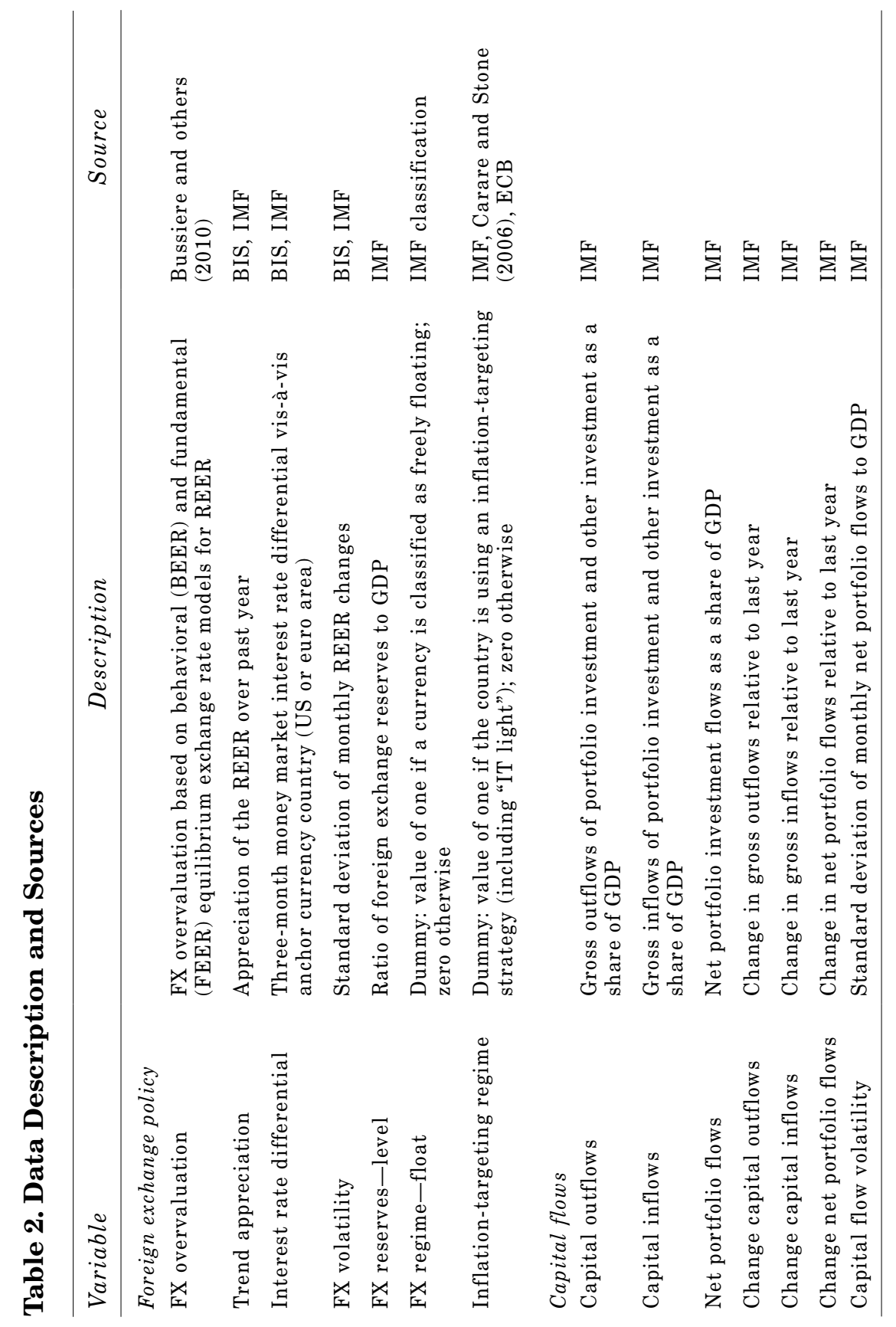




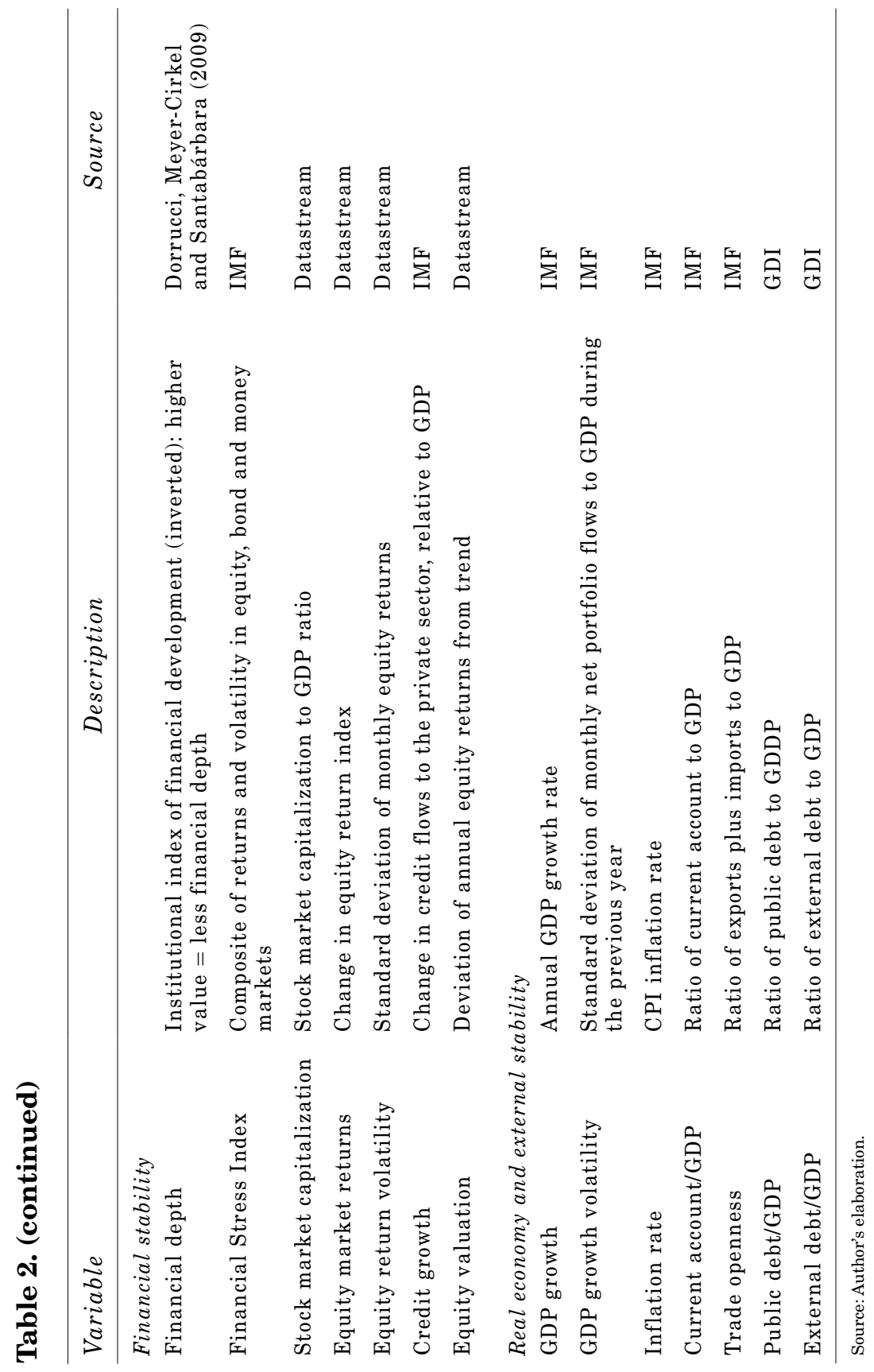


Table 3. Summary Statistics

\begin{tabular}{|c|c|c|c|c|}
\hline Variable & Mean & Std. Deviation & Minimum & Maximum \\
\hline \multicolumn{5}{|l|}{ Foreign exchange policy } \\
\hline FX overvaluation & 7.175 & 17.663 & -21.649 & 45.700 \\
\hline Trend appreciation & -0.005 & 0.127 & -19.922 & 26.606 \\
\hline Interest rate differential & 7.530 & 18.671 & -7.810 & 69.150 \\
\hline FX volatility & 0.034 & 0.064 & 0.000 & 1.735 \\
\hline FX reserves-level & 0.136 & 0.154 & 0.036 & 1.583 \\
\hline FX regime-float & 0.143 & 0.350 & 0.000 & 1.000 \\
\hline Inflation-targeting regime & 0.133 & 0.340 & 0.000 & 1.000 \\
\hline \multicolumn{5}{|l|}{ Capital flows } \\
\hline Capital outflows & -0.001 & 0.275 & -0.402 & 0.853 \\
\hline Capital inflows & 0.001 & 0.189 & -0.544 & 0.505 \\
\hline Net portfolio flows & 0.004 & 0.067 & -0.737 & 0.750 \\
\hline Change capital outflows & -0.007 & 0.339 & -0.284 & 0.190 \\
\hline Change capital inflows & 0.003 & 0.218 & -0.298 & 0.233 \\
\hline Change net portfolio flows & -0.001 & 0.068 & -0.402 & 0.382 \\
\hline Capital flow volatility & 0.036 & 0.087 & 0.000 & 0.853 \\
\hline \multicolumn{5}{|l|}{ Financial stability } \\
\hline Financial depth & 0.428 & 0.627 & 0.000 & 8.125 \\
\hline Financial Stress Index & -0.069 & 2.707 & -5.619 & 15.150 \\
\hline Stock market capitalization & 0.473 & 0.602 & 0.000 & 2.425 \\
\hline Equity market returns & 0.007 & 0.043 & -0.169 & 0.773 \\
\hline Equity return volatility & 0.033 & 0.034 & 0.000 & 1.094 \\
\hline Credit growth & 1.971 & 23.057 & 0.003 & 52.104 \\
\hline Equity valuation & 7.175 & 17.663 & -21.649 & 45.700 \\
\hline \multicolumn{5}{|c|}{ Real economy and external stability } \\
\hline GDP growth & 0.040 & 0.027 & -0.151 & 0.177 \\
\hline GDP growth volatility & 0.013 & 0.012 & 0.001 & 0.113 \\
\hline Inflation rate & 8.331 & 5.394 & -2.176 & 267.067 \\
\hline Current account/GDP & -0.004 & 0.051 & -0.224 & 0.238 \\
\hline Trade openness & 0.816 & 0.473 & 0.003 & 4.729 \\
\hline Public debt/GDP & 0.584 & 0.392 & 0.050 & 2.898 \\
\hline External debt/GDP & 0.177 & 0.282 & 0.003 & 0.734 \\
\hline
\end{tabular}

Source: Author's elaboration. 
As to the hypothesis that capital controls are related to foreign exchange policy, seven foreign exchange variables are analyzed. A first key variable is the degree of exchange rate misalignment, so as to test whether having an undervalued or overvalued exchange rate is associated with a different level of capital controls and whether it triggers active decisions by policymakers to raise or lower existing restrictions. The main measure of foreign exchange overvaluation used stems from behavioral (BEER) and fundamental (FEER) equilibrium exchange rate models for real effective exchange rates. As this variable is an important focus of the present paper, several alternative proxies for foreign exchange misalignment are used and based on deviations from a linear trend or from period averages of real effective exchange rates (REER), nominal effective exchange rates (NEER) and bilateral exchange rates vis-à-vis the main anchor currencies. While the estimates shown below are based on the foreign exchange overvaluation measures from the structural BEER and FEER models, those estimates are robust to using such proxies of misalignments from trend. ${ }^{12}$

Policymakers may also react to other foreign exchange policy variables in their decision about capital controls, including the past trend appreciation of the REER, the three-month money market interest rate differential vis-à-vis the anchor currency country and the exchange rate volatility (measured as the standard deviation of monthly REER movements during the previous year). All these variables are included in the model estimation of equations (1) and (2) and are based on lagged values (the previous year) so as to take into account the fact that changes in capital controls are likely to affect foreign exchange variables themselves contemporaneously.

In addition, the test of the foreign exchange policy hypothesis includes the level of foreign exchange reserves as a share of GDP, a dummy for the exchange rate regime (taking the value of one if a currency is classified by the IMF as being freely floating) and a dummy for whether countries have an inflation-targeting monetary policy strategy (taking a value of one if the country is targeting inflation). The priors are that countries with a floating exchange rate regime and an inflation-targeting regime are more likely to have fewer restrictions on

12. Data for REER and NEER are from the Bank for International Settlements (BIS) and the IMF. Bilateral exchange rates are mostly taken vis-à-vis the US dollar, with the exception of European currencies, for which the euro that is taken as the anchor currency. 
capital flows. The prior for foreign exchange reserves is more difficult to gauge. On one hand, foreign exchange reserve accumulation and a fixed exchange rate regime may be complements, as both may be used to stabilize the country's currency. This would imply that more reserves are linked to more capital account restrictions. On the other hand, foreign exchange reserves and capital account openness may be negatively correlated, in that a country with a closed capital account may not need to intervene heavily in foreign exchange markets to stabilize the domestic currency.

As to the second hypothesis, the capital flow hypothesis, the level, change and volatility of capital flows are used as proxies to gauge whether capital controls are related to fluctuations in capital flows. Overall capital inflows and outflows (portfolio flows plus other investment flows, which mostly includes bank loans) and, more narrowly, net portfolio flows are analyzed in the empirical test. Changes in flows are percentage changes relative to the previous year; the volatility of flows is the standard deviation of monthly flows.

All capital flow proxies are measured as a share of GDP. This is an important point to keep in mind because when for example, people talk about "excessive" capital flows, they may have different benchmarks in mind. For instance, a given volume of capital inflows may not be large when measured against the overall size of the economy, but these flows may be very large relative to the size of the domestic financial sector. The reason for normalizing flows by GDP is to be able to distinguish the size of capital flows per se from the importance of other factors and characteristics, which are analyzed separately under the financial stability hypothesis below.

Third, a number of alternative proxies are used to test for the role of a financial stability objective of capital controls. Institutional indicators of financial sector development and stock market capitalization relative to GDP are employed as two alternative proxies for a country's financial market depth and development. The prior is that policymakers are more likely to maintain a higher level of capital controls or raise capital controls when the domestic financial sector is more shallow, causing external and domestic shocks to have an adverse effect on the domestic financial system and the domestic economy.

As a second dimension, the analysis tests for the role of financial stress; the prior is that higher financial stress should be positively correlated with capital control measures. The IMF's financial stress index (which is a composite of returns and volatility in equity, bond and money markets) and specifically equity market volatility 
(standard deviation of monthly returns) are used as proxies. Third, to capture the role of overheating and asset price bubbles, the analysis includes credit growth (the change in credit flows to the private sector, relative to GDP), the change in domestic equity returns and the deviation of equity returns from period averages (equity valuation) as proxies. The prior here is clear, with more financial stress or asset price rises in the previous year expected to be positively related to capital controls.

As to the fourth and final hypothesis, the role of the real economy and external stability for the choice of capital flow management measures, the GDP growth rate, GDP growth volatility (standard deviation of quarterly growth rates over the past two years), the consumer price index (CPI) inflation rate, the ratio of the current account to GDP, trade openness (exports plus imports over GDP), the ratio of public debt to GDP and the ratio of external debt to GDP are included. Most priors as to the relationship with capital controls are clear with regard to these proxies, possibly with the exception of trade openness. On one hand, more trade openness may imply that a country is more exposed to external shocks, potentially providing an incentive for domestic policymakers to try to shield the domestic economy from such shocks by restricting the mobility of capital into and out of the country. On the other hand, the literature contains solid evidence that capital flows piggy back trade, that is, that there is a positive relationship between the two for financing and risksharing motives.

\section{Testing the Four Hypotheses: The Empirical Results}

This section presents and discusses the results, systematically discussing each of the four hypotheses in turn.

\subsection{Foreign Exchange Policy}

The analysis first turns to the role of foreign exchange policy as a motivation for capital controls. Table 4 presents the estimates of equation (1) for the level of controls, while table 5 shows the estimates for equation (2) for the changes in controls. The last columns of each table indicate the conceptual prior about the expected signs of the coefficients, based on the discussion in the previous section. For 


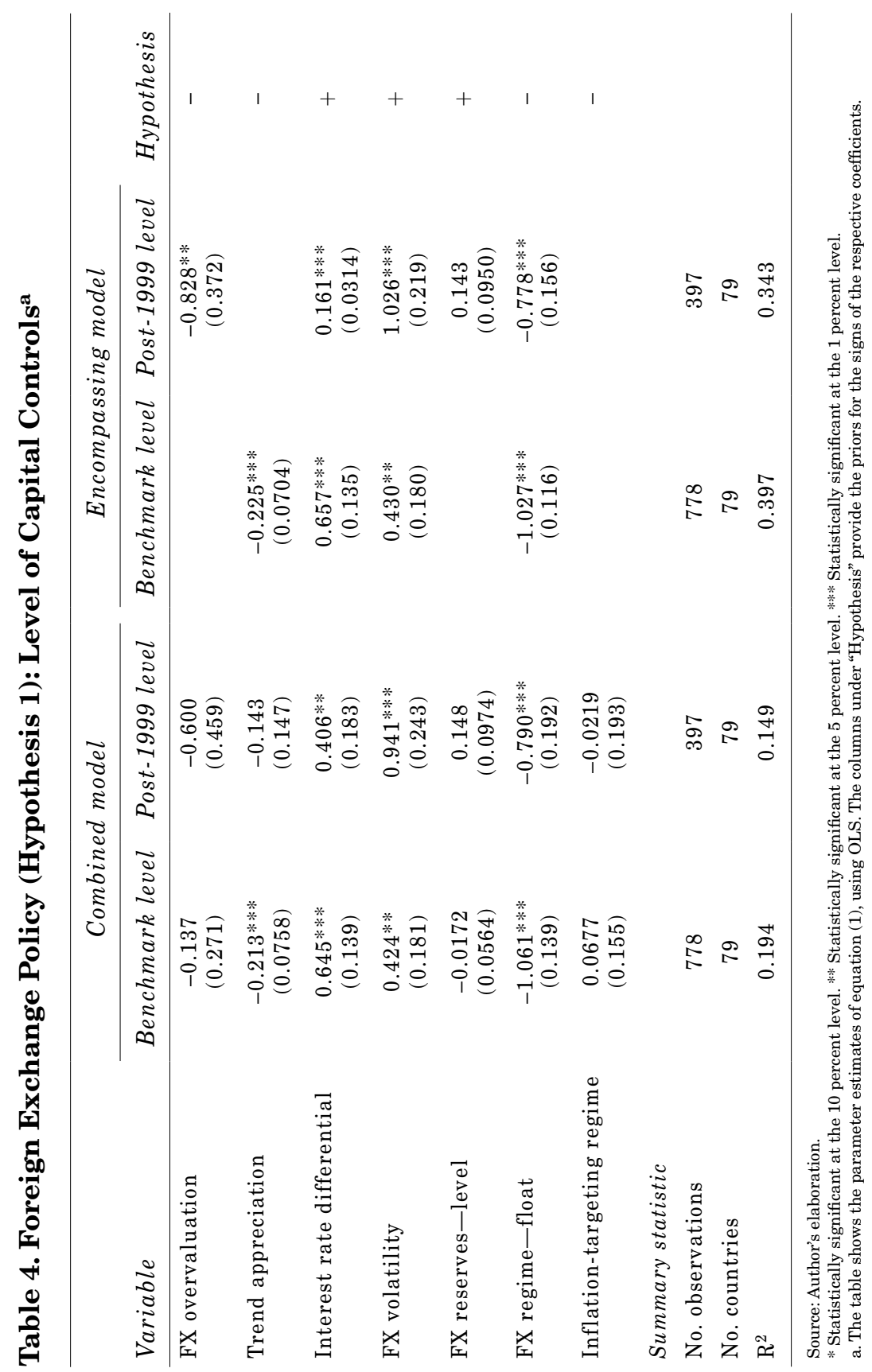




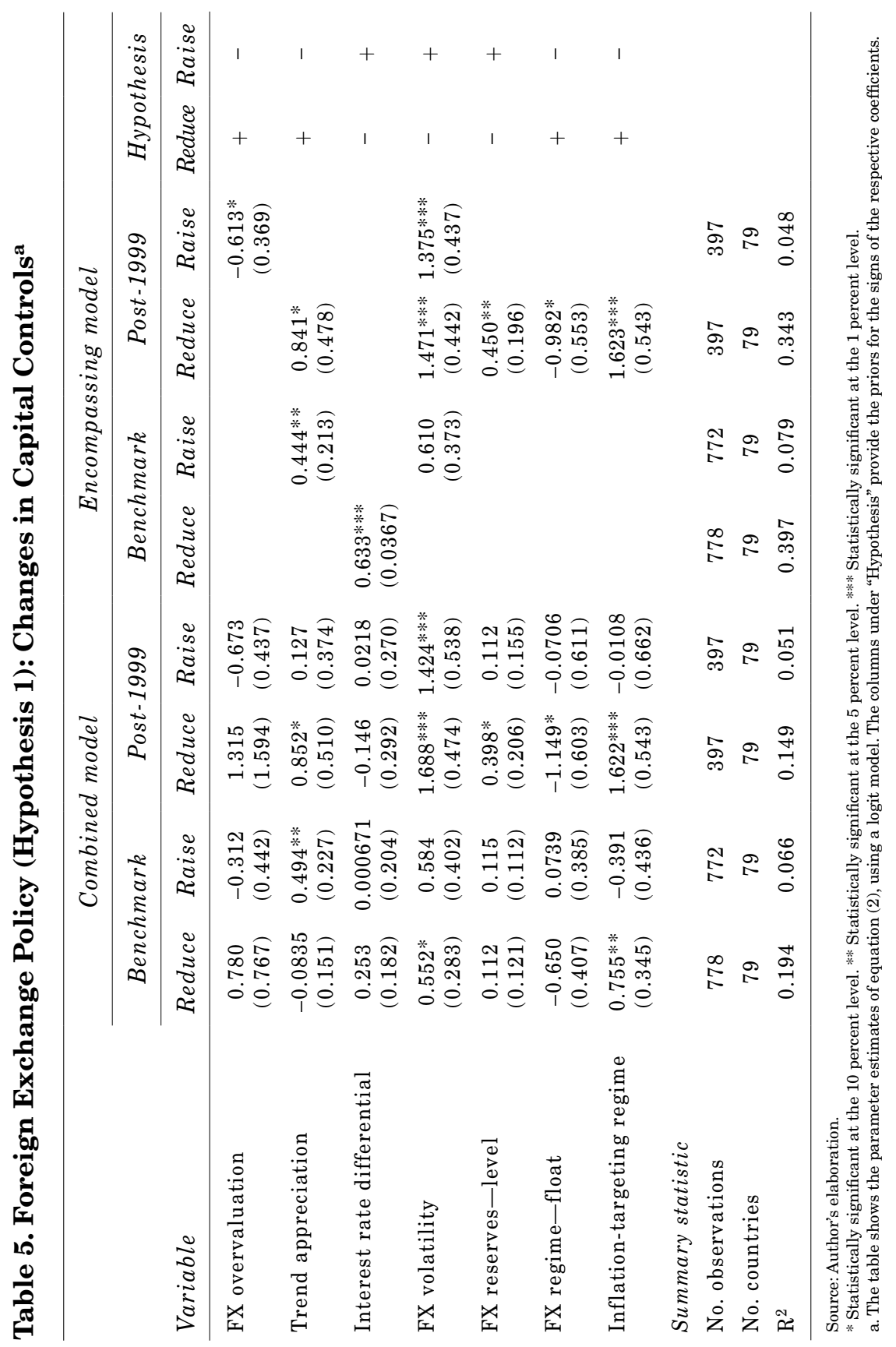


each hypothesis, three types of models are estimated and presented: individual models including each factor separately; a combined model capturing all factors of a particular hypothesis together; and an encompassing model that includes only those factors that are statistically significant at the 20 percent level.

Overall, there is significant evidence that the level and changes in capital controls are related to foreign exchange policy. In particular, there is a close link between the undervaluation of exchange rates and capital control policies. Since 1999, an undervalued exchange rate is associated with a higher level of capital controls. Moreover, countries with undervalued exchange rates are more likely to have raised capital controls since 1999 .

Capital controls are also significantly related to other elements of concern for foreign exchange policy: higher REER volatility is associated with a higher level of capital controls (especially since 1999) and is more likely to trigger an increase in capital controls. Similarly, a trend depreciation of the REER is also linked to both a higher level and a lower probability of policymakers reducing capital controls since 1999.

Another key dimension connecting capital controls and foreign exchange policy is the country's exchange rate regime and underlying monetary policy regime. Containing the volatility and volume of capital flows through capital controls may make it easier for policymakers to maintain a fixed exchange rate regime. Countries with a flexible currency regime and an inflation-targeting monetary policy regime are less likely to need capital controls to achieve their policy objectives. The findings of the empirical analysis are consistent with this argument, as countries with a flexible exchange rate regime or an inflation-targeting regime tend to be more open financially. Moreover, since 1999 countries with inflation-targeting regimes have much more frequently reduced existing capital controls than nontargeting countries.

Table 6 tries to gauge the relevance of the various factors by looking at the interdecile range of the marginal effects. Concretely, the table displays how much the capital control measure is explained, on average, by differences in each of the factors analyzed when comparing countries with a value of a factor at the tenth percentile of the entire distribution (of countries and over time) with countries with a value of the same factor at the ninetieth percentile of the distribution. For instance, a country with a high degree of overvaluation at a particular point in time (that is, at the ninetieth percentile of the foreign exchange overvaluation variable) has a level of capital controls that is 2.55 
Table 6. Economic Relevance of Alternative Hypotheses

\begin{tabular}{|c|c|c|}
\hline Variable & Hypothesis & Interdecile $^{a}$ \\
\hline \multicolumn{3}{|l|}{$F X$ policy } \\
\hline FX overvaluation & - & -2.55 \\
\hline Trend appreciation & - & -0.27 \\
\hline Interest rate differential & + & 0.14 \\
\hline FX volatility & + & 1.73 \\
\hline FX reserves-level & + & 0.21 \\
\hline FX regime-float & - & -0.77 \\
\hline Inflation-targeting regime & - & \\
\hline \multicolumn{3}{|l|}{ Capital flows } \\
\hline Capital outflows & + & -0.33 \\
\hline Capital inflows & + & -0.21 \\
\hline Net portfolio flows & + & 0.19 \\
\hline Change capital outflows & + & -0.09 \\
\hline Change capital inflows & + & \\
\hline Change net portfolio flows & + & -0.24 \\
\hline Capital flow volatility & + & 0.13 \\
\hline \multicolumn{3}{|l|}{ Financial stability } \\
\hline Financial depth & - & -0.59 \\
\hline Financial Stress Index & $+1 ?$ & -0.34 \\
\hline Stock market capitalization & - & -1.10 \\
\hline Equity market returns & - & \\
\hline Equity return volatility & + & 0.21 \\
\hline Credit growth & $+1 ?$ & 1.66 \\
\hline Equity valuation & - & -0.55 \\
\hline \multicolumn{3}{|l|}{ Real economy } \\
\hline GDP growth & - & 0.32 \\
\hline GDP growth volatility & + & 0.34 \\
\hline Inflation rate & + & 0.84 \\
\hline Current account/GDP & - & -0.20 \\
\hline Trade openness & $-1 ?$ & -0.29 \\
\hline Public debt/GDP & + & \\
\hline External debt/GDP & + & -0.14 \\
\hline
\end{tabular}

Source: Author's elaboration.

a. The column labeled "Interdecile" shows the difference in the level of capital controls for a country with the respective factor at its $90^{\text {th }}$ percentile compared to a country with the same factor at the $10^{\text {th }}$ percentile. 
lower, on average, than a country with a low degree of overvaluation (that is, a high degree of undervaluation, at the tenth percentile of the foreign exchange overvaluation variable). The value of 2.55 is about one full standard deviation of the capital control level variable, which is a quite sizeable magnitude.

Figure 3 provides a visualization of the relationship between the level of capital controls and first, foreign exchange overvaluation and, second, the foreign exchange volatility variable. The fit is particularly

\section{Figure 3. Capital Controls and Exchange Rate Policy ${ }^{\mathrm{a}}$}

\section{A. Foreign exchange overvaluation}

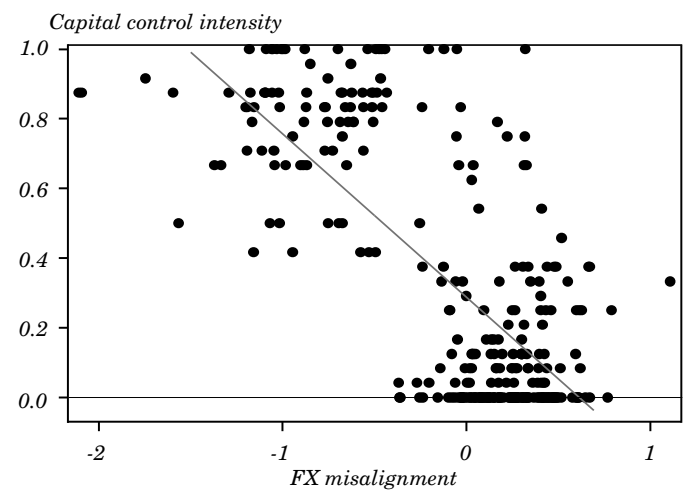

B. Foreign exchange volatility

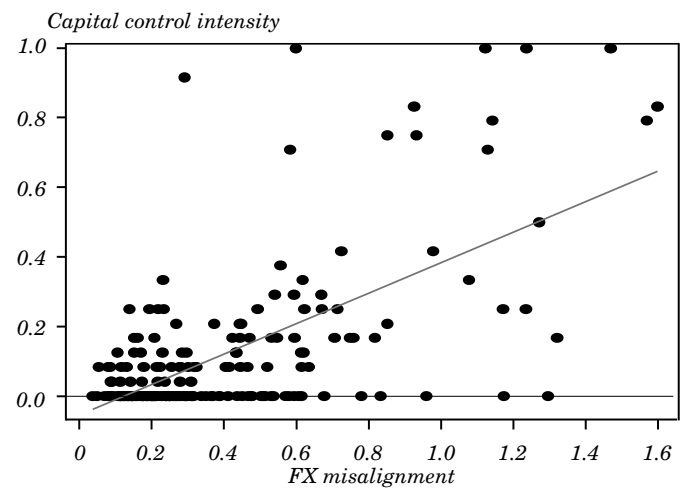

Source: Author's elaboration.

a. The figure shows the values of the capital control measure against the values for foreign exhcange overvaluation (panel A) and volatility (panel B) for all countries and each year in the precrisis period (2003-07). 
good in the relationship between overvaluation and capital controls across countries and over time.

For the event study, figure 4 shows the evolution of four of the foreign exchange policy variables around changes in capital controls (either increases or reductions). In particular, the event study indicates that the degree of undervaluation increases in the years following large rises in capital controls. Moreover, countries with high exchange rate volatility not only tend to have significantly higher levels of capital controls, but are also more likely to raise capital controls.

The evidence for inflation targeting is also striking. Countries with inflation-targeting regimes are much more likely to reduce capital controls than keep them constant. By contrast, countries that

Figure 4. Foreign Exchange Policy: Evolution around Changes in Capital Controls ${ }^{a}$

\section{A. FX valuation}

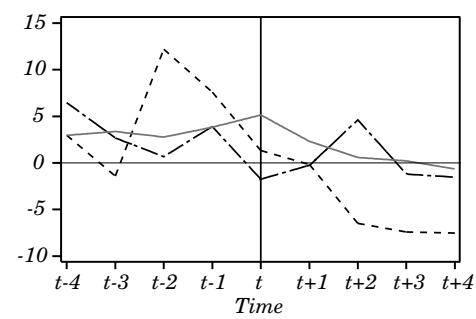

C. Inflation Targeting regime

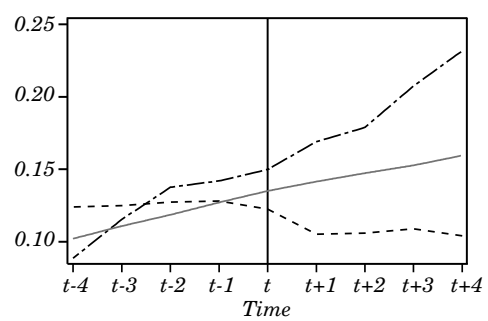

\section{B. FX volatility}

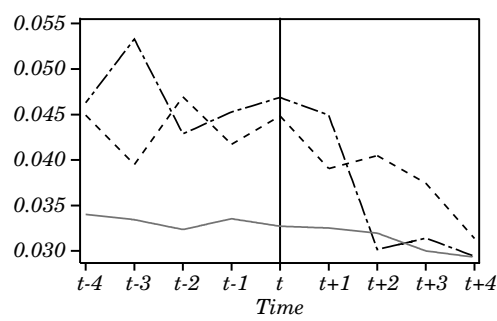

D. FX Regime (de facto floating)

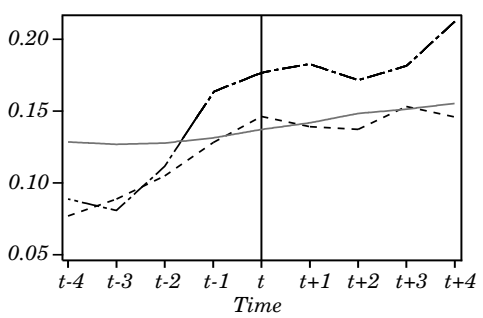

No change

Source: Author's elaboration.

a. The figures show the evolution of variables around changes in capital controls (either increases or reductions), compared with countries with no changes. The horizontal axis indicates the four years before and after these changes. 
raise capital controls are less likely to have an inflation-targeting regime in the years after raising capital controls.

Finally, I conducted a battery of robustness tests to check for the sensitivity of the estimates. Table 7 presents the benchmark estimates when using the alternative capital control measure by Schindler (2009). The table indicates that the estimates are qualitatively very similar to those using the Chinn-Ito measure. Next, table 8 provides estimates when splitting controls on inflows from controls on outflows. The findings overall are qualitatively very similar for controls on inflows and outflows. Similarly, distinguishing across country groups does not yield systematically different findings, though some coefficients lose or gain significance in alternative models (table 9). Several other robustness tests were conducted that are not shown here for brevity reasons. ${ }^{13}$

In summary, the evidence shown points quite strongly toward foreign exchange policy motives being an important objective behind capital control policies, both for maintaining a high level of capital controls and for raising capital controls at times. This is particularly the case with regard to maintaining undervalued exchange rates.

\subsection{Capital Flows}

The section turns to analyzing the potential role of the second hypothesis, namely, whether and to what extent capital flow management policies are influenced by a capital flow objective. Overall, tables 10 and 11 indicate that there is no compelling evidence that either the level of or changes in capital flows per se are an important motive for capital controls. In fact, higher levels of gross capital inflows, gross capital outflows and changes in net portfolio flows are associated with a lower level of capital controls (table 10). Moreover, having experienced higher capital inflows, portfolio inflows or net portfolio flow volatility in the previous year reduces the probability of a country raising capital controls (table 11).

13. For instance, one of the strengths of the Schindler measure is that it allows distinguishing between controls across different types of investment. Again, the estimates did not show a pattern that would point toward systematic differences across categories. Moreover, equation (2) for changes was also estimated using these alternative capital control proxies, with similar empirical findings as for the presented benchmark results. The same holds for the estimates for the other three hypotheses. 


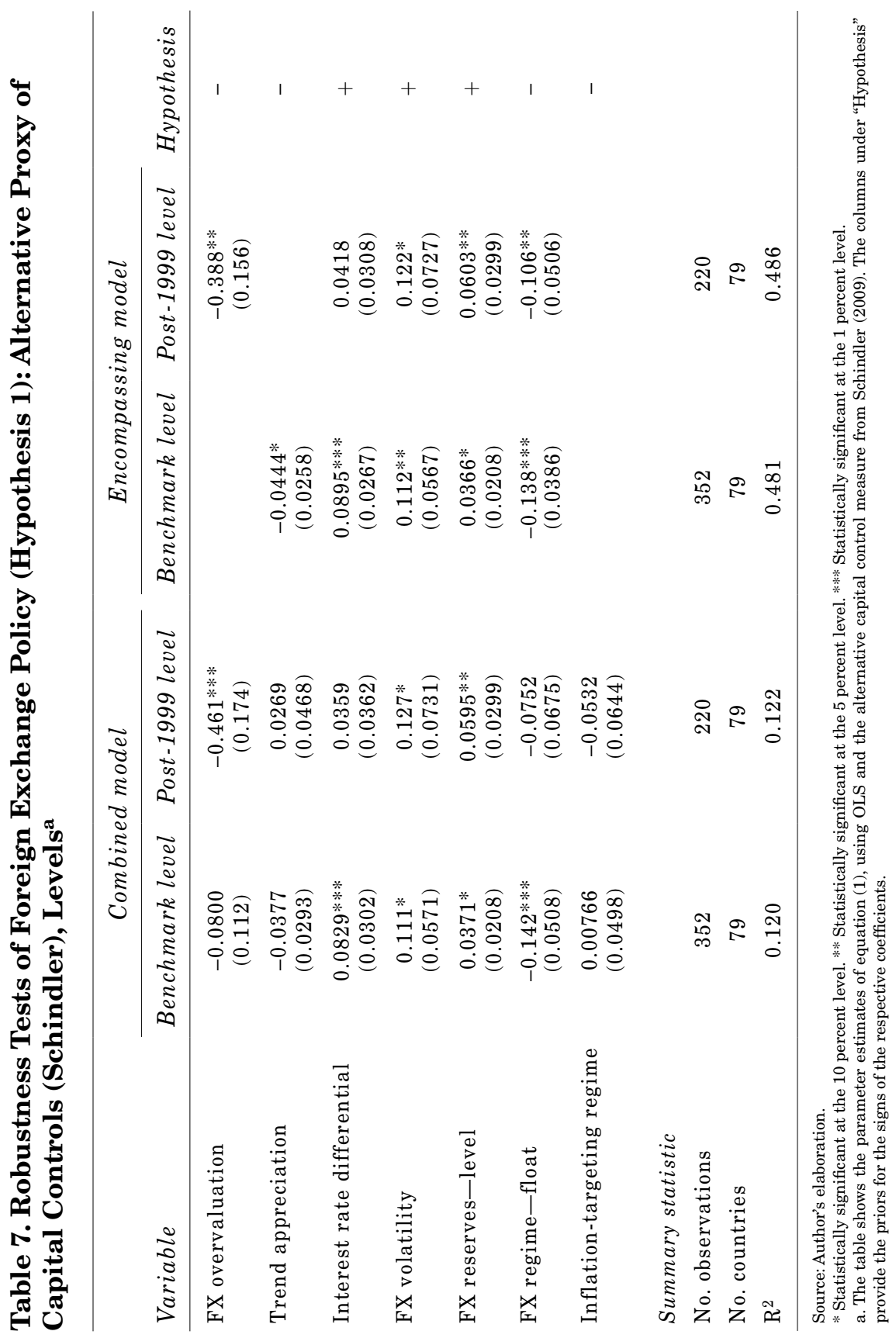




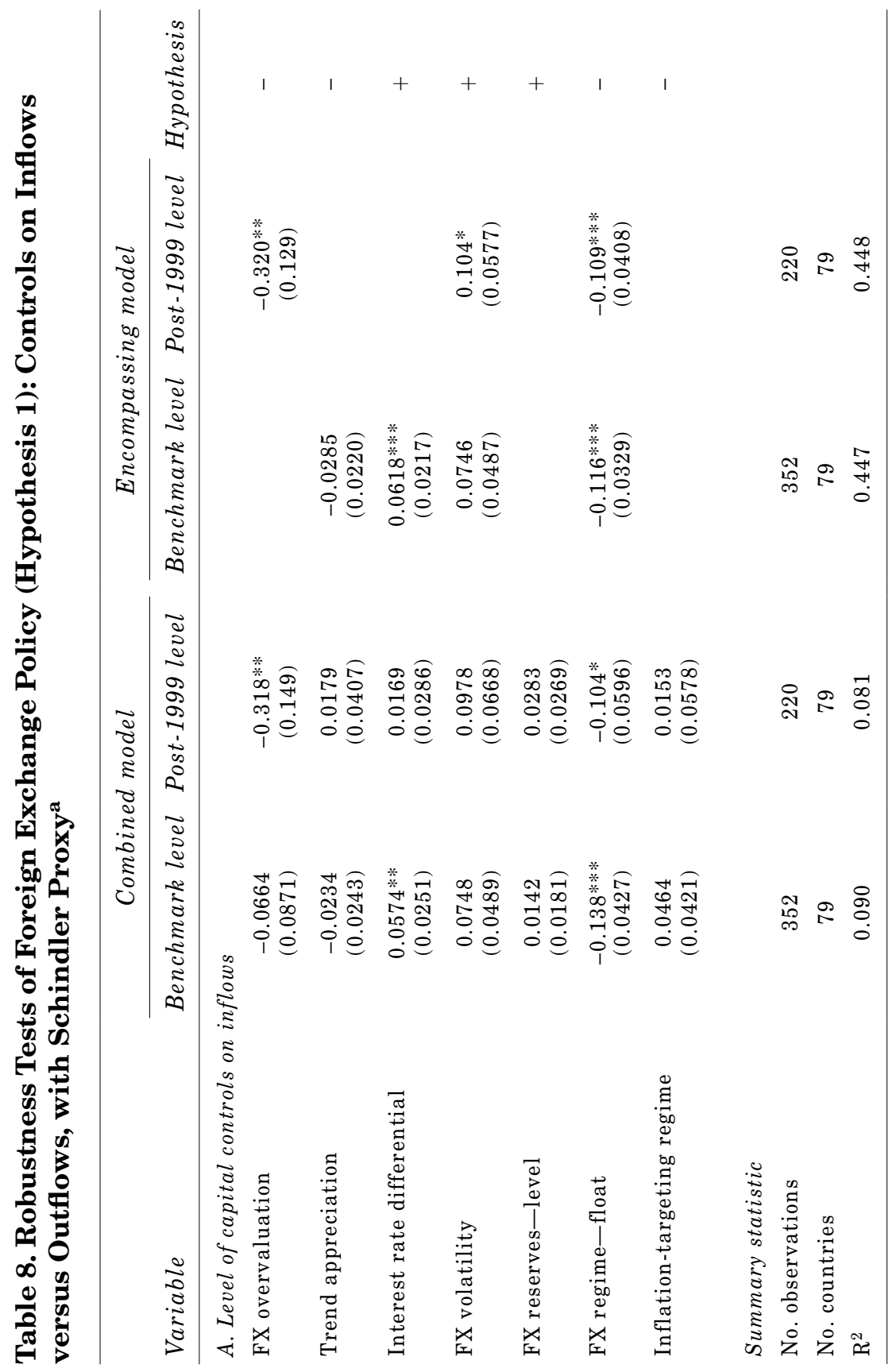




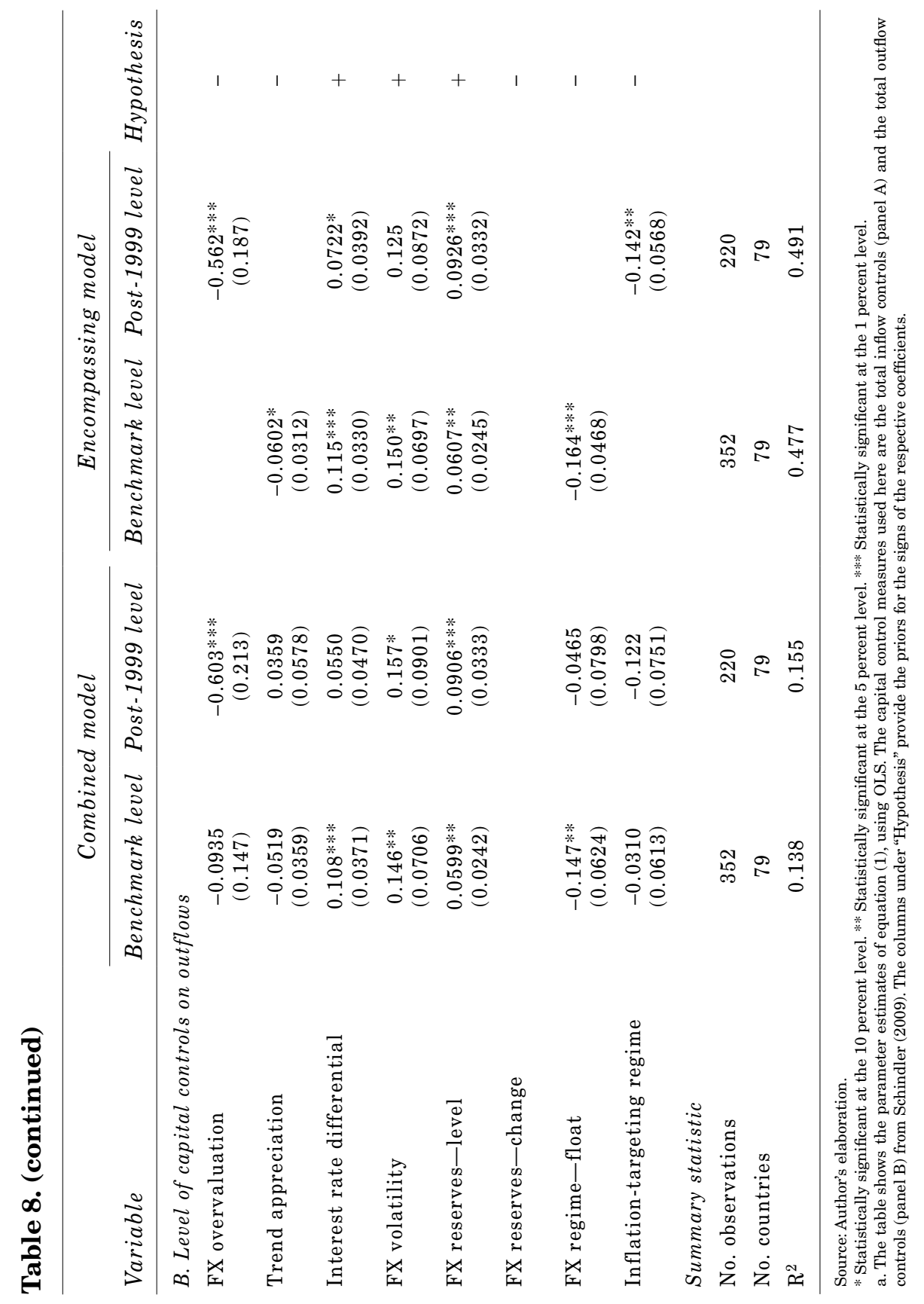




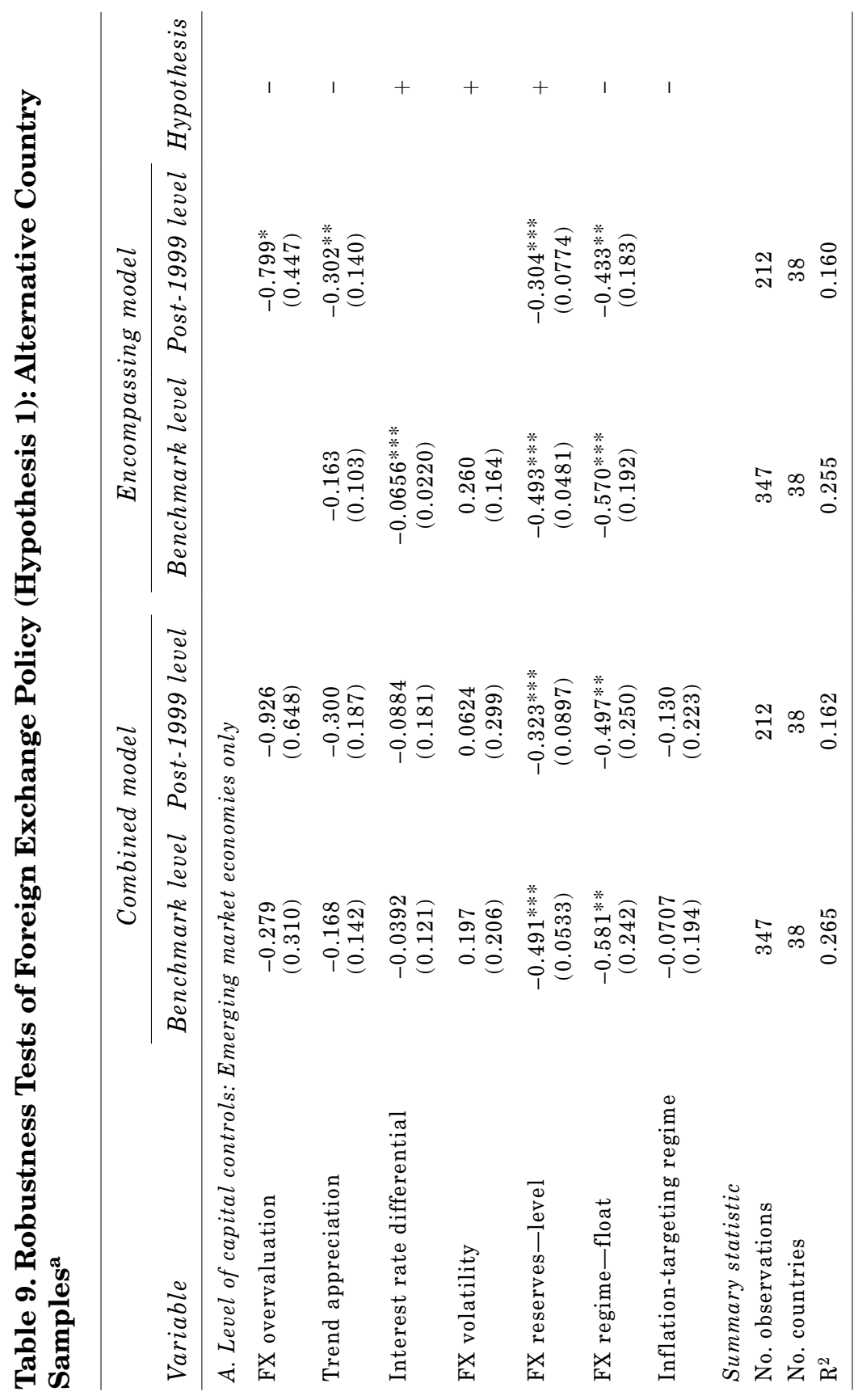




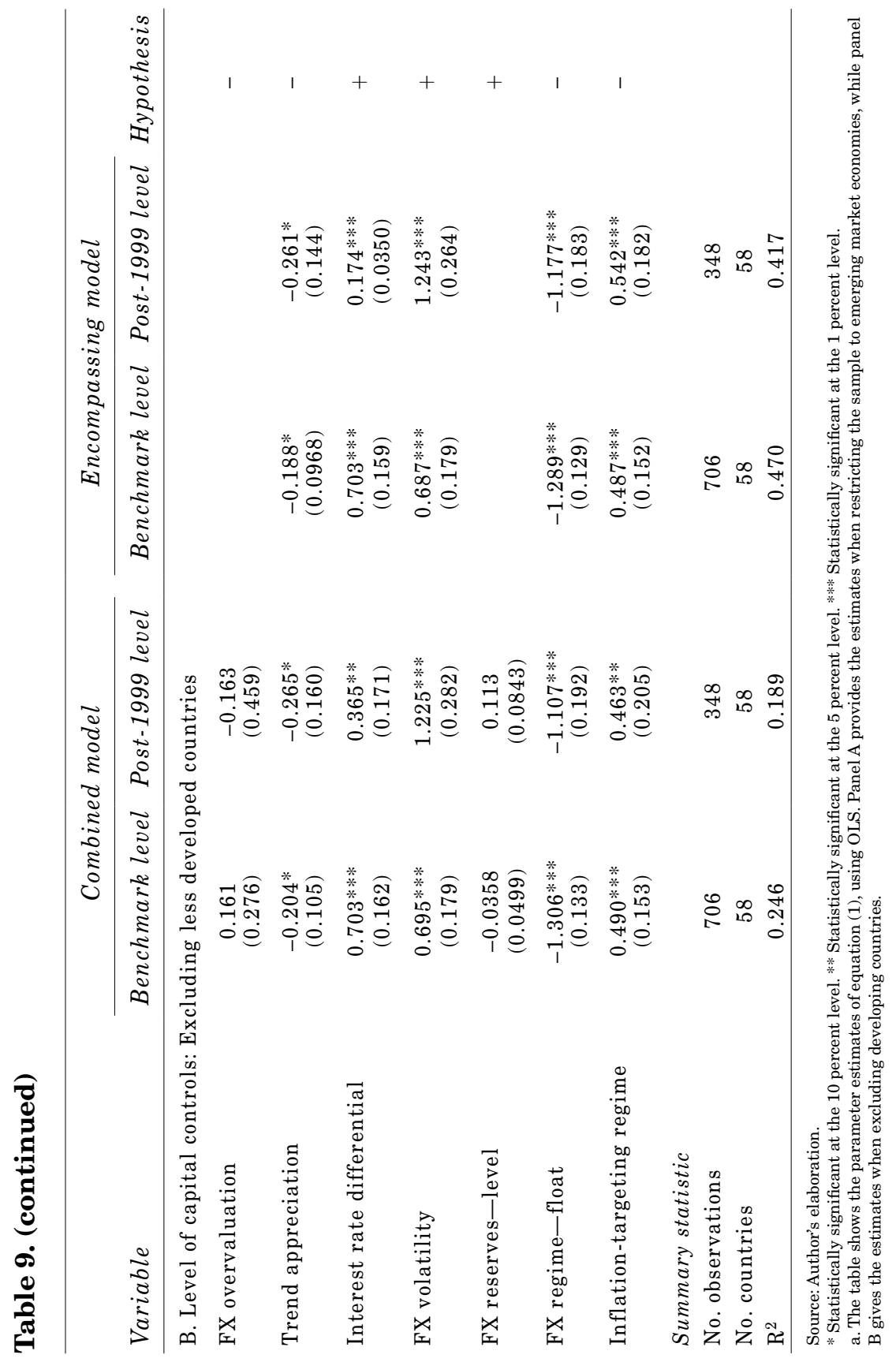




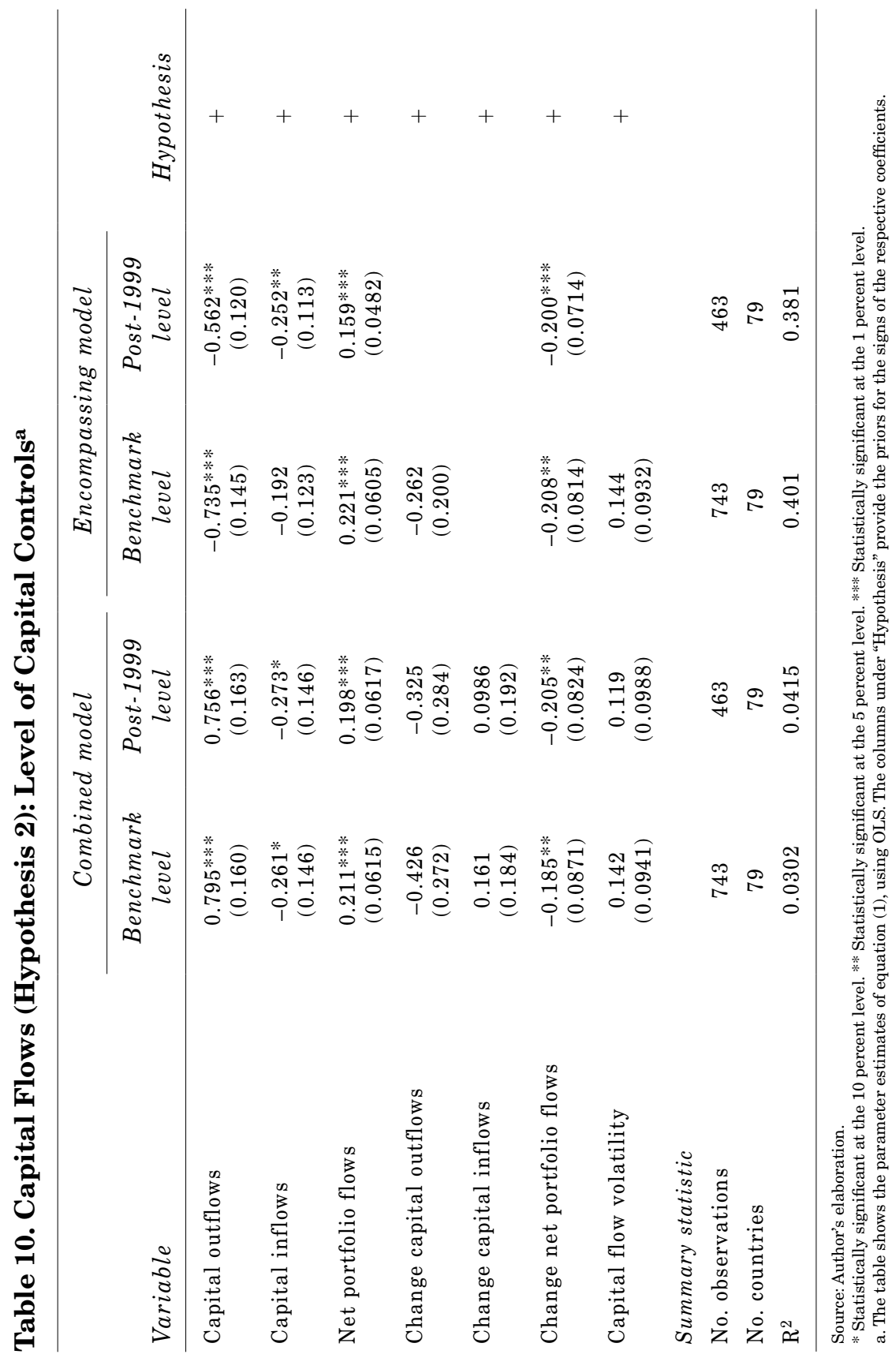




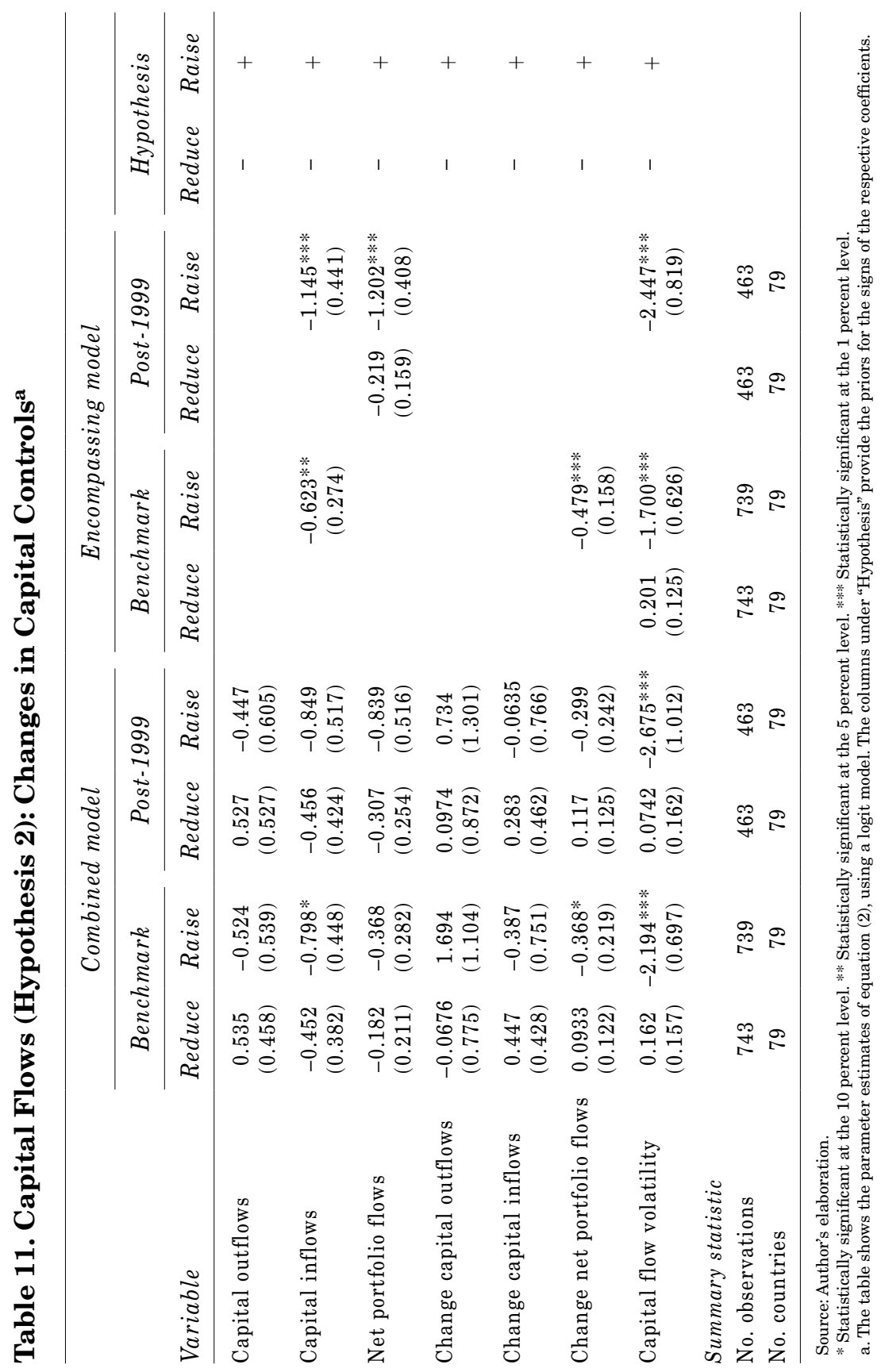


These findings underline the importance of being cautious in not necessarily interpreting these findings in a causal way. Countries with high capital flows are likely to be different in many other ways from countries with a relatively lower volume or volatility of capital flows. Specifically, capital flows here are measured relative to the size of the domestic economy, rather than the size of the domestic financial sector. As discussed above, this was a deliberate choice to distinguish the size and volatility of capital flows per se from other potential factors influencing the choice of capital controls, such as factors related to financial stability objectives.

Nevertheless, an important finding emerging from the analysis here is that there is no systematic evidence that links a larger magnitude and a higher volatility of capital flows per se with more capital flow restrictions. This evidence is corroborated by the event study of illustrated in figure 5, which shows that net portfolio flows decline in the years following significant increases in capital controls.

\section{Figure 5. Capital Flows: Evolution around Changes in Capital Controls ${ }^{a}$}

A. Capital inflows

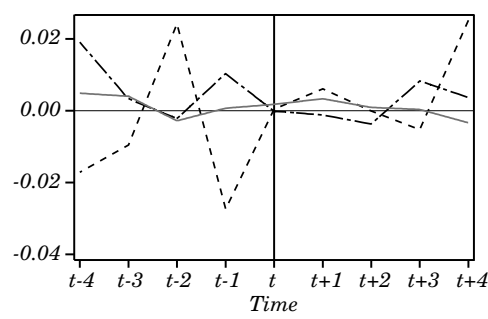

C. Change portfolio flows

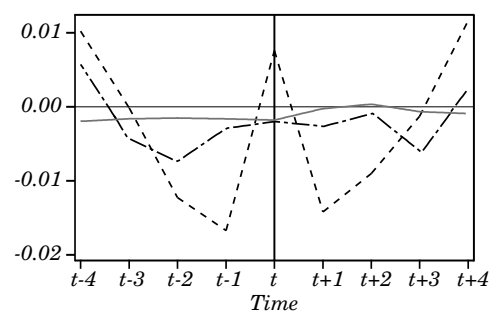

B. Net portfolio flows

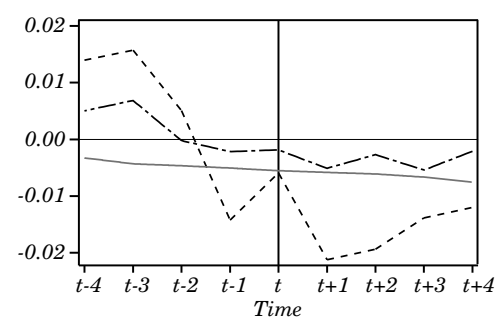

D. Capital flow volatility

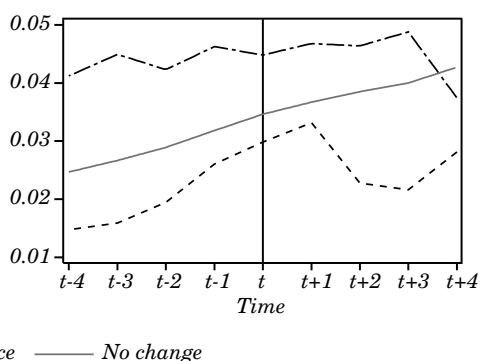

Source: Author's elaboration.

a. The figures show the evolution of variables around changes in capital controls (either increases or reductions), compared with countries with no changes. The horizontal axis indicates the four years before and after these changes. 


\subsection{Financial Stability}

The third hypothesis relates to the role of financial stability objectives for policymakers to choose a capital control regime. The evidence shown in tables 12 and 13 uncovers an ambiguous relationship between financial stability objectives and the level and changes in capital controls. Countries with deeper financial markets have a lower level of capital controls and are also less likely to raise capital controls. This holds for both proxies of financial market depth, the institutional indicator ("financial depth") and the market-based measure ("stock market capitalization").

Second, countries with more financial stress (in bond, equity and money markets) in prior years tend to have lower levels of capital controls and are also more likely to liberalize their capital account.

Third, the evidence is much stronger for the role of credit growth. Here the findings suggest that countries with high rates of credit growth to the private sector in the previous year not only have a higher level of capital controls, but are also more likely to raise existing controls further. Table 6 indicates that this effect is indeed economically meaningful, as the credit growth variable is one of the three most important variables in terms of the magnitude explained of the differences in the level of capital controls across countries and over time.

The event study shown in figure 6 indicates that credit growth not only is higher in prior years for countries deciding to raise capital controls than for those lowering controls or keeping them constant, but also declines markedly during and after the (re-)introduction or raising of capital controls.

Overall, the evidence on financial stability suggests that it is not financial market stress that motivates decisions about raising and maintaining high levels of capital controls, but rather the credit growth rate that is linked to capital control measures. This points to policymakers' concerns about an overheating of the real economy rather than about financial markets per se.

\subsection{Real Economy and External Stability}

As to the fourth and final hypothesis, namely, the role of real economy and external stability objectives for capital control measures, the evidence reported in tables 14 and 15 indicates that countries with high inflation and high volatility in GDP growth both 


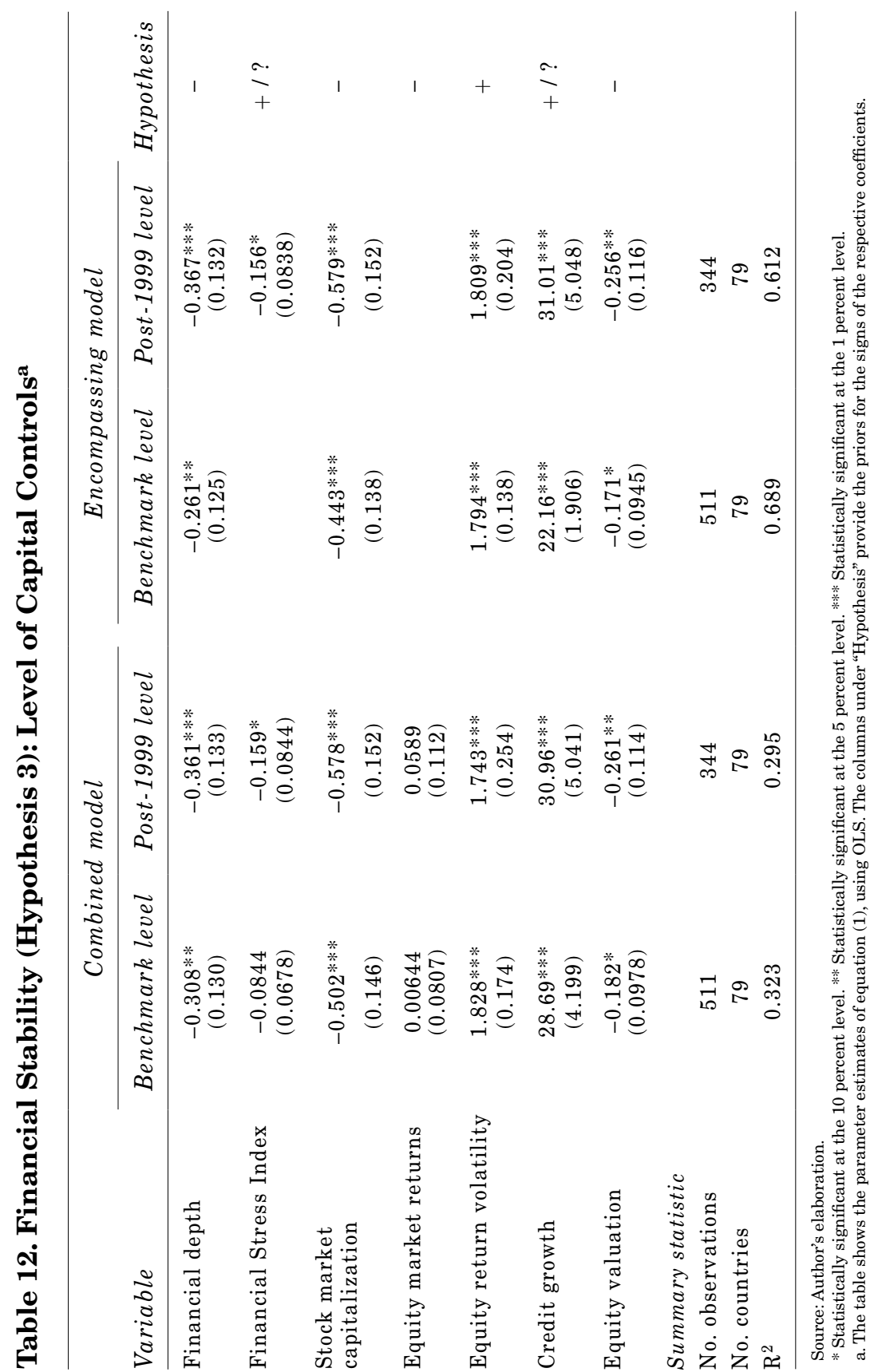




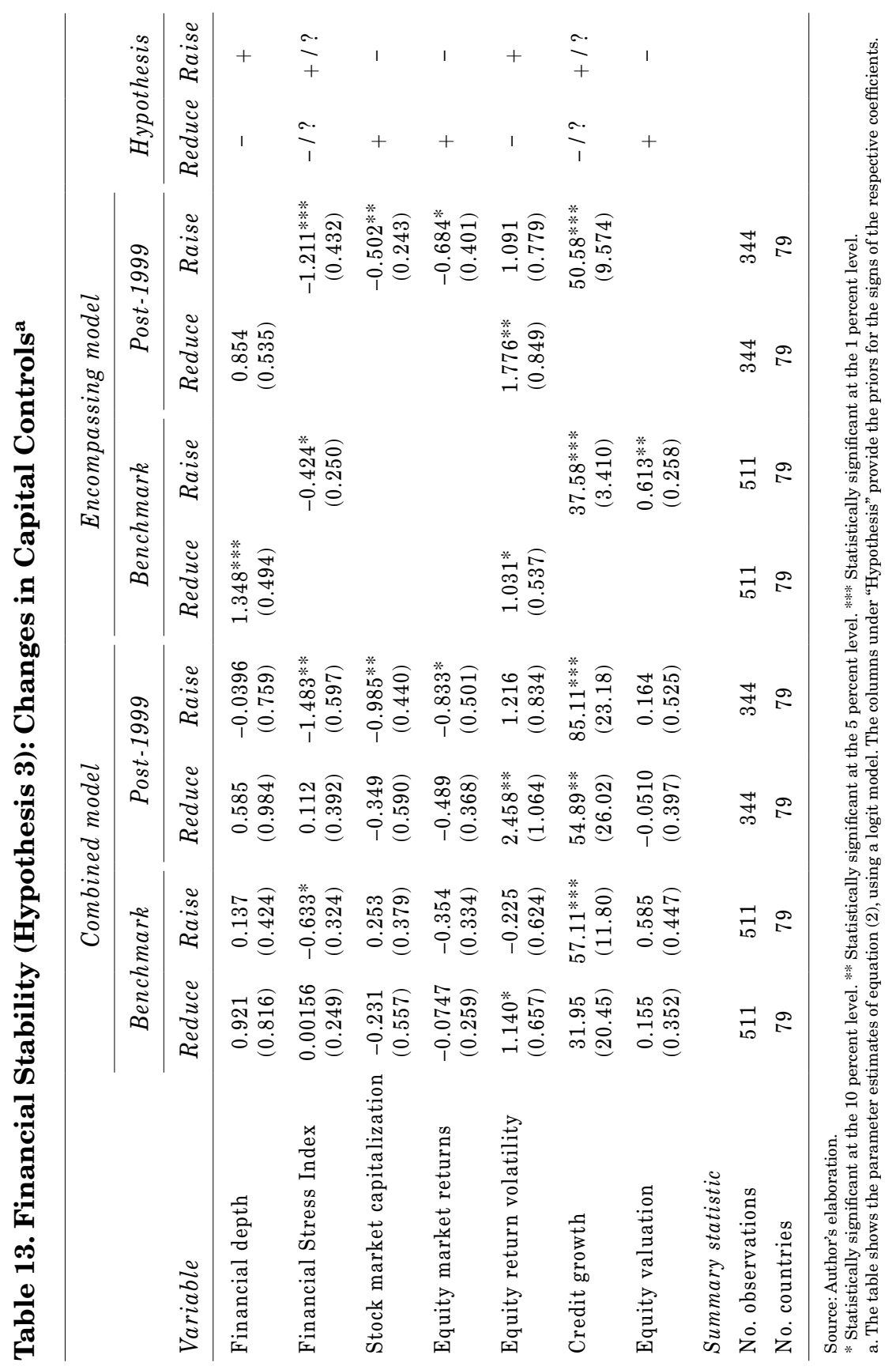




\section{Figure 6. Financial Stability: Evolution around Changes in Capital Controls ${ }^{a}$}

\section{A. Finantial stress index}

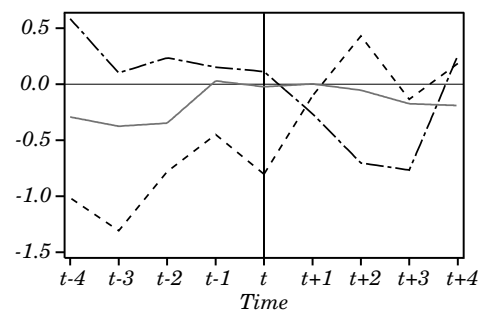

C. Equity market volatility

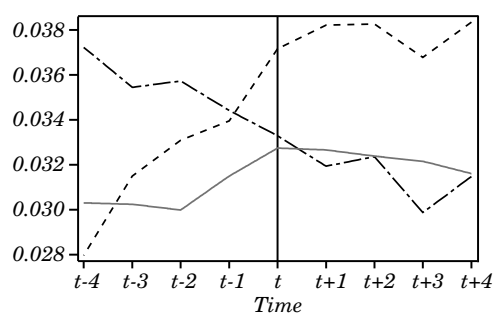

\section{B. Stock market capitalization}

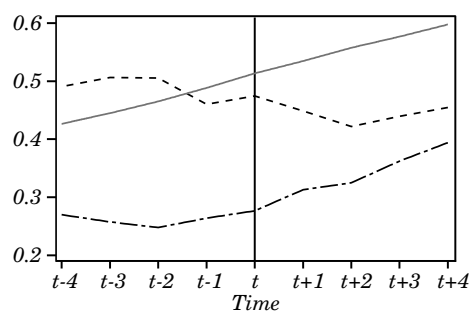

D. Credit growth

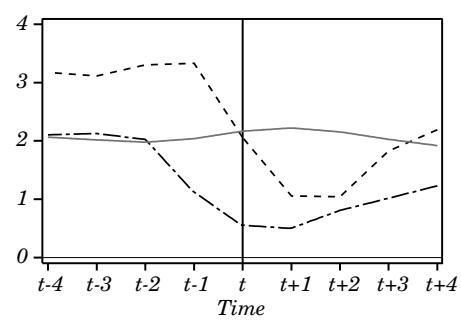

No change

Source: Author's elaboration

a. The figures show the evolution of variables around changes in capital controls (either increases or reductions), compared with countries with no changes. The horizontal axis indicates the four years before and after these changes.

have a higher a level of capital controls and are more likely to raise existing capital controls. By contrast, countries that are more open to trade tend to have lower levels of capital controls and are more likely to reduce existing controls. This confirms the prior that there is a positive relationship between trade and financial openness, as discussed earlier.

Moreover, there is little evidence that levels and changes in capital controls are systematically linked to the level of public debt or external debt. After 1999, however, there is some indication that countries with a higher external debt have been less likely to lower capital controls and more likely to keep existing restrictions.

As to the event study of figure 7, there is no indication that either inflation rates or GDP volatility decline in the years after the 


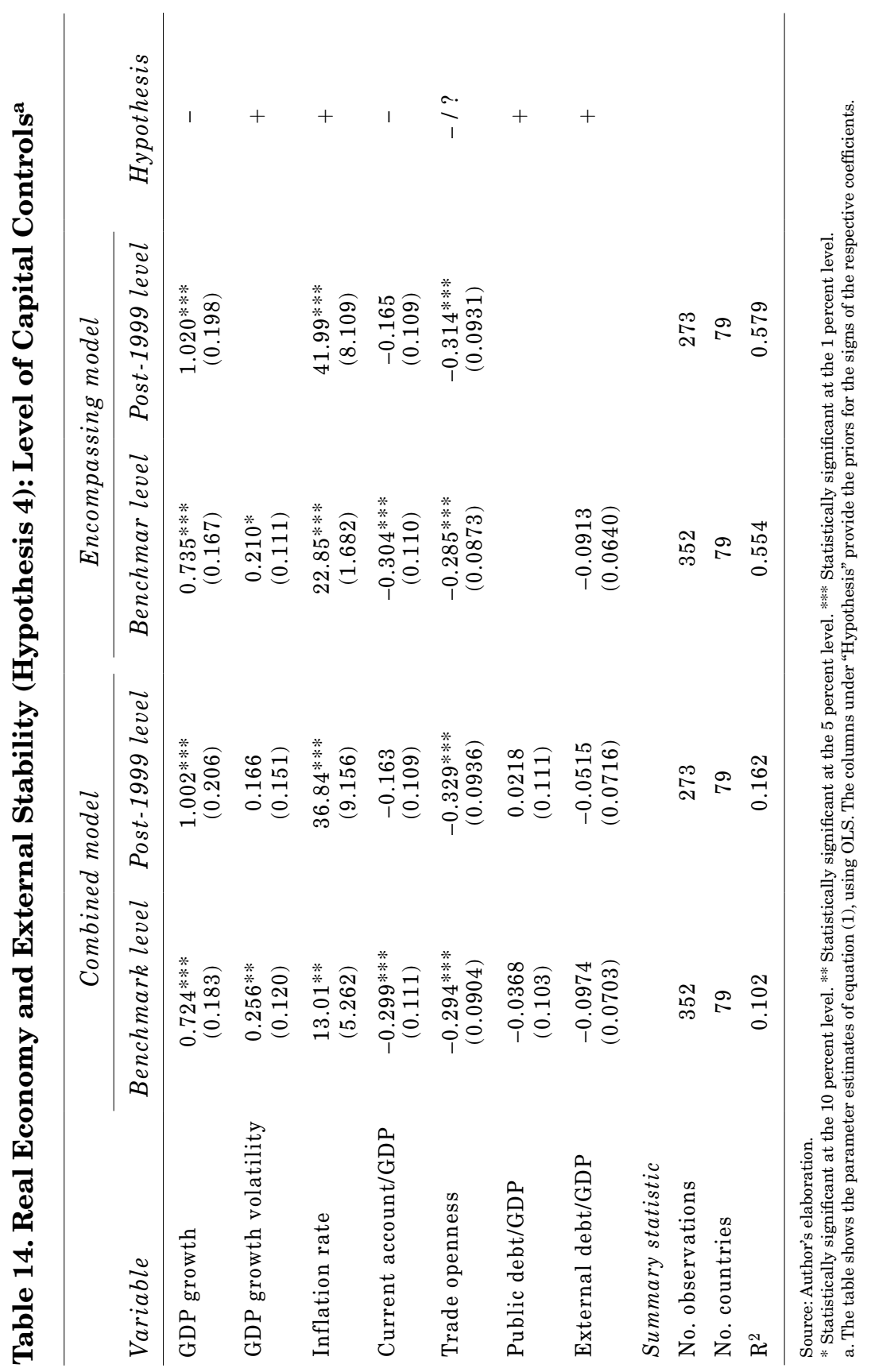




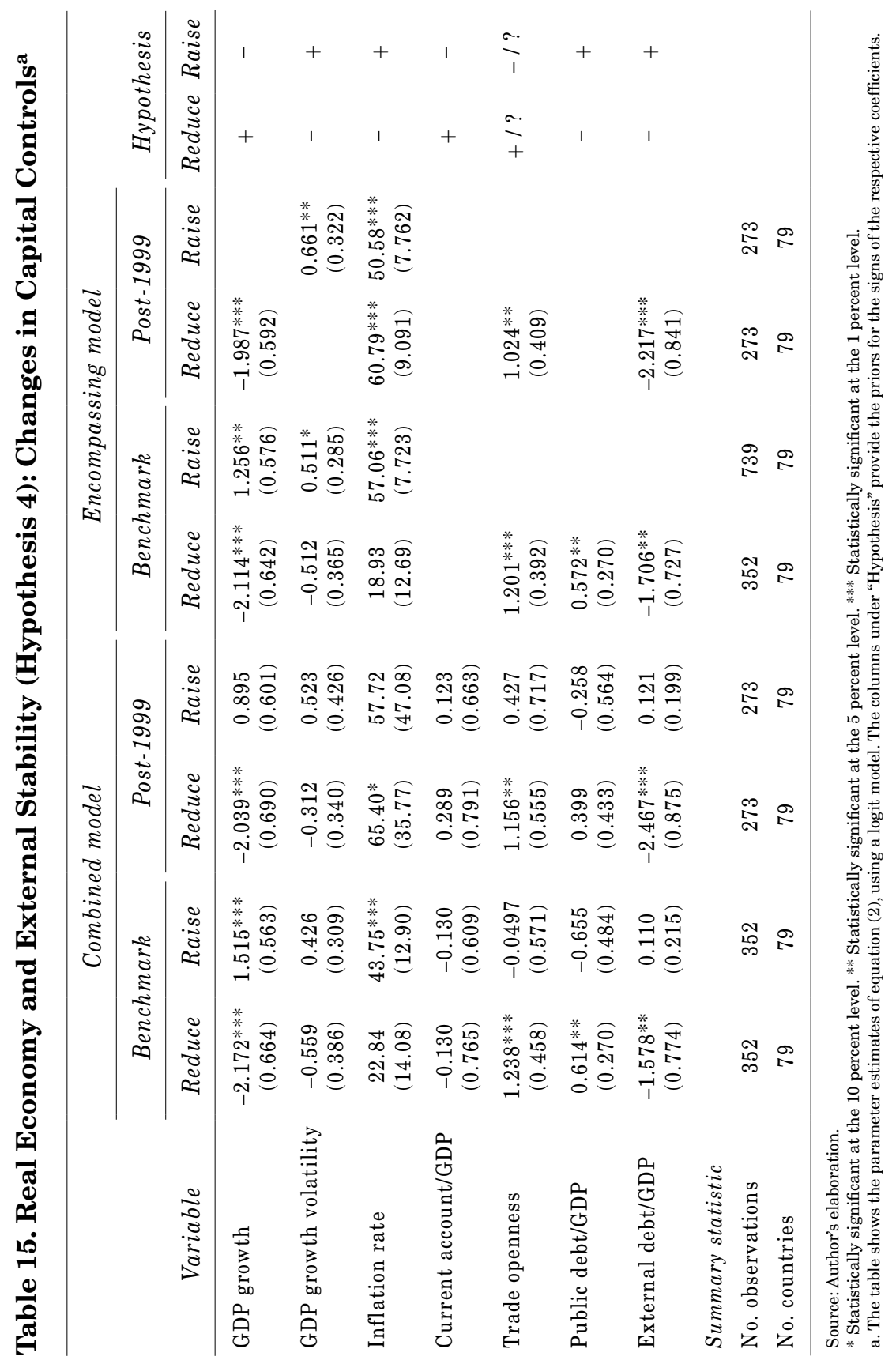




\section{Figure 7. Real Economy and External Objectives: Evolution around Changes in Capital Controls ${ }^{a}$}

A. Real GDP growth

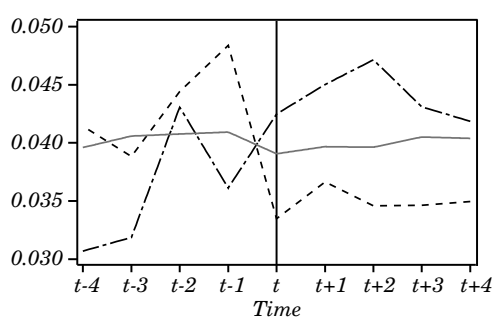

C. Inflation rate

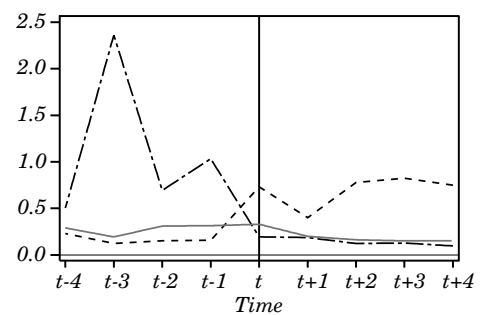

B. Real GDP volatility

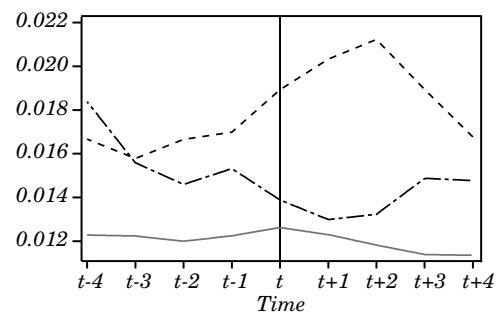

D. Current account/GDP

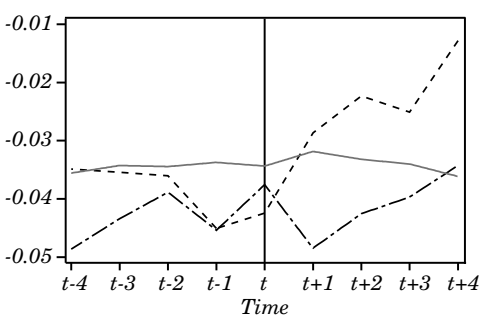

No change

Source: Author's elaboration.

a. The figures show the evolution of variables around changes in capital controls (either increases or reductions), compared with countries with no changes. The horizontal axis indicates the four years before and after these changes.

introduction of capital controls. Again, this needs to be interpreted cautiously, since there is no proper counterfactual of what would have happened to these variables if capital controls had not been changed for these countries. Nevertheless, the results are suggestive that a reduction in inflation and output volatility did not materialize rapidly after capital controls were increased.

\subsection{Joint Test of Four Hypotheses}

As the final step of the analysis, the various hypotheses are tested jointly together in a single estimation. A key challenge of estimating all four hypotheses individually is, of course, that variables for different hypotheses may be correlated with one another, so tests of 
individual hypotheses may suffer from an omitted variable bias. On the other hand, given the large number of variables, it is impossible to combine all four hypotheses in a meaningful way by including all variables simultaneously in the estimations.

As a middle way between these two, I choose to focus on those variables that have been identified as important determinants in the individual hypothesis tests above. In particular, the overvaluation and foreign exchange regime variables are included for the foreign exchange hypothesis, credit growth and inflation as proxies for overheating, and financial depth is used to capture the degree of financial market development.

Another possible determinant of capital controls, which was discussed in detail in the introduction, is a potential externality of capital controls, in that high controls or the raising of capital controls in some countries may make it more likely for other countries to follow suit. Such an externality may be captured by including an additional variable ("Capital controls region") that measures the average level or average change of capital controls in the region in the previous year.

Table 16 shows the parameter estimates for this combined test of equation (1) for the level estimations, using OLS, and equation (2) for the estimation for changes in capital controls, using a logit model. All of the findings for the single-hypothesis tests above are confirmed when the different variables are combined in a single model. The only variable that loses significance somewhat is the financial depth variable. Moreover, the variable of capital controls in the region to capture externalities from capital controls is highly significant and large in magnitude. For the estimation for changes, this implies that countries are more likely to raise or lower controls when other countries in the region have done so recently. In addition, the magnitude of the coefficients becomes much larger after 1999, suggesting that such externalities have become more important in the 2000 s.

Overall, the evidence on the real economy and on financial stability suggest that in making the decision to raise or maintain capital controls, policymakers are more concerned about an overheating of the economy-in the form of high credit growth, rising inflation and output volatility-than about narrow financial market issues. 


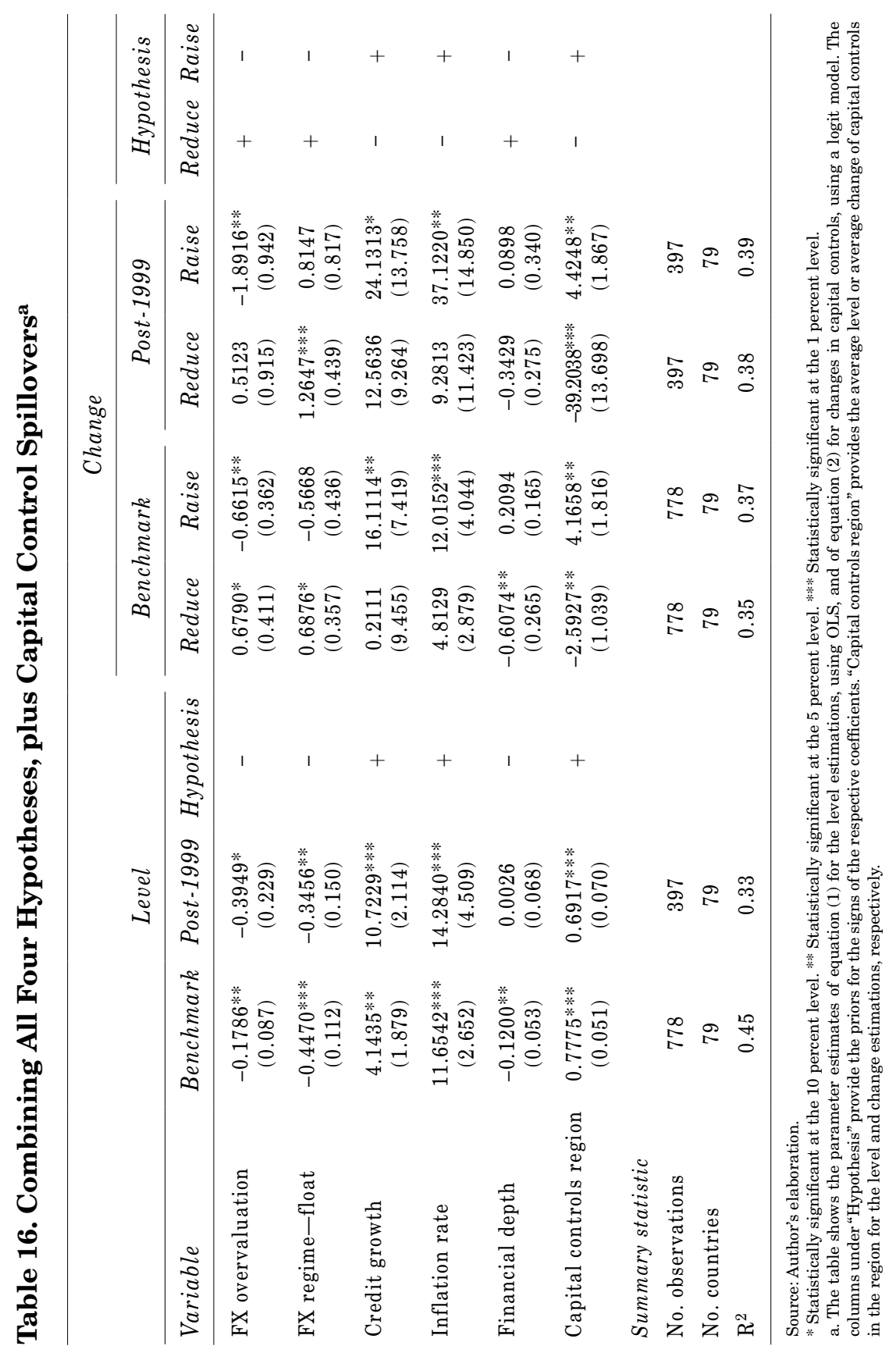




\section{Conclusions}

The intention of the paper has been to gauge policymakers' motives in using capital controls as an active policy tool. Hence, the intended contribution of the present paper is not to analyze whether capital controls are effective in achieving their objectivesas a sizeable literature has been trying to establish-but rather to understand what drives policymakers in their decisions to use capital flow restrictions.

The findings of the paper suggest that foreign exchange policy management has been a central motive for policymakers who use capital controls. Countries with a high level of capital controls and countries that are actively raising existing controls tend to have undervalued exchange rates and a high degree of exchange rate volatility.

Moreover, the choice of capital flow restrictions is closely linked to countries' choices about their exchange rate and monetary policy regimes. The findings of the paper suggest that countries with a high level of capital flow restrictions tend to have fixed exchange rates and monetary policy regimes other than inflation targeting. Moreover, countries with fixed exchange rates and nontargeting regimes have been much more likely to raise capital controls over the past decade.

The analysis of the paper finds no systematic evidence for a link between capital controls and a high volume or volatility of capital flows per se. There is also no compelling evidence that policy decisions about capital controls are related to a high degree of financial market stress or volatility. It seems that choices about capital flow restrictions, in particular over the past decade, have been largely motivated by concerns about an overheating of the domestic economy-in the form of high credit growth, inflation and output volatility.

Taken together, the evidence suggests that both a foreign exchange policy objective and concerns about domestic overheating are the key motives for capital flow management policies over the past decade. Hence, capital controls have not merely been associated with preventing an overvaluation or appreciation of the domestic currency, but rather with a significant undervaluation of the exchange rate. This provides support to those who warn against the use of policies that trigger competitive devaluations and currency wars.

The evidence further indicates that capital controls may frequently be used to compensate for the absence of autonomous and 
independent monetary policy. Countries that have fixed exchange rate regimes and shallow financial markets have little ability to use monetary policy to deal with domestic overheating pressures. Even relatively modest capital inflows and volatility in flows pose a serious challenge to domestic policymakers and may induce them to use capital flow restrictions.

Putting these pieces of evidence together makes it hard to see how capital flow management policies can be a first-best solution to domestic policy challenges. The imposition of capital controls may help to buy time for domestic policymakers to address underlying economic, institutional and policy weaknesses at home, yet the risk is that these policy choices become entrenched and reduce the urgency and incentives of policymakers to address the true root causes of domestic vulnerabilities to fluctuations in capital flows. The persistence and frequent re-introduction of capital control measures in recent years suggest that this risk may become a reality. 


\section{REFERENCES}

Aizenman, J. and V. Sushko. 2011. "Capital Flows: Catalyst or Hindrance to Economic Takeoffs?" Working Paper 17258. Cambridge, Mass.: National Bureau of Economic Research.

Bekaert, G., M. Ehrmann, M. Fratzscher, and A. Mehl. 2011. "Global Crises and Equity Market Contagion.” Working Paper 17121. Cambridge, Mass.: National Bureau of Economic Research.

Broner, F., R.G. Gelos, and C. Reinhart. 2006. "When in Peril, Retrench: Testing the Portfolio Channel of Contagion." Journal of International Economics 69(1): 203-30.

Bussiere, M., M. Ca' Zorzi, A. Chudik, and A. Dieppe 2010. "Methodological Advances in the Assessment of Equilibrium Exchange Rates.” Working Paper 1151. Frankfurt: European Central Bank.

Calvo, G., A. Izquierdo, and L.F. Mejía. 2011. "Systemic Sudden Stops: The Relevance of Balance-Sheet Effects and Financial Integration.” Working Paper 14026. Cambridge, Mass.: National Bureau of Economic Research.

Calvo, G., L. Leiderman, and C. Reinhart. 1996. "Inflows of Capital to Developing Countries in the 1990s." Journal of Economic Perspectives 10(2): 123-39.

Carare, A. and M. Stone. 2006. "Inflation Targeting Regimes." European Economic Review 50(5): 1297-1315.

Cardarelli, R., S. Elekdag, and M.A. Kose. 2009. "Capital Inflows: Macroeconomic Implications and Policy Responses." Working Paper 40. Washington: International Monetary Fund.

Chamon, M., A. Ghosh, J. Ostry, and M. Qureshi. 2011. "Managing Capital Inflows: The Role of Controls and Prudential Policies." Working Paper 17363. Cambridge, Mass.: National Bureau of Economic Research.

Chinn, M. and H. Ito. 2008. "A New Measure of Financial Openness." Journal of Comparative Policy Analysis 10(3): 309-22.

_. 2011. "The Chinn-Ito Index: A de Jure Measure of Financial Openness." University of Wisconsin at Madison. Available online at http://web.pdx.edu/ ito/Chinn-Ito_website.htm.

Cowan, K. and J. De Gregorio. 2007. "International Borrowing, Capital Controls and the Exchange Rate: Lessons from Chile." In Capital Controls and Capital Flows in Emerging Economies: Policies, Practices and Consequences, edited by S. Edwards, pp. 241-96. University of Chicago Press. 
Cowan, K., J. De Gregorio, A. Micco, and C. Neilson. 2008. "Financial Diversification, Sudden Stops and Sudden Starts." In Current Account and External Finance, edited by K. Cowan, S. Edwards and R. Valdés. Santiago: Central Bank of Chile.

Curcuru, S., C. Thomas, F. Warnock, and J. Wongswan. 2011. "US International Equity Investment and Past and Prospective Returns." American Economic Review 101(7): 3440-55.

Dorrucci, E., A. Meyer-Cirkel, and D. Santabárbara. 2009. "Domestic Financial Development in Emerging Economies: Evidence and Implications." Occasional Paper 102. Frankfurt: European Central Bank.

Forbes, K. 2007. "The Microeconomic Evidence on Capital Controls: No Free Lunch." In Capital Controls and Capital Flows in Emerging Economies: Policies, Practices and Consequences, edited by S. Edwards, pp. 171-202. University of Chicago Press.

Forbes, K., M. Fratzscher, T. Kostka, and R. Straub. 2012. "Bubble Thy Neighbor: Portfolio Effects and Externalities from Capital Controls." Working Paper 18052. Cambridge, Mass.: National Bureau of Economic Research.

Forbes, K. and F. Warnock. 2011. "Capital Flow Waves: Surges, Stops, Flight and Retrenchment." Working Paper 17351. Cambridge, Mass.: National Bureau of Economic Research.

Fratzscher, M. 2011. "Capital Flows, Global Shocks and the 2007-08 Financial Crisis.” Working Paper 17357. Cambridge, Mass.: National Bureau of Economic Research.

Gelos, R.G. and S.J. Wei. 2005. "Transparency and International Portfolio Holdings.” Journal of Finance 60(6): 2987-3020

Hau, H. and H. Rey. 2005. "Exchange Rates, Equity Prices and Capital Flows.” Review of Financial Studies 19(1): 273-317.

Henry, P.B. 2007. "Capital Account Liberalization: Theory, Evidence and Speculation." Journal of Economic Literature 45(4): 887-935.

Jeanne, O. 2011. "Who Needs to Open the Capital Account?" Washington: Peterson Institute of International Economics.

Korinek, A. 2010. "Regulating Capital Flows to Emerging Markets: An Externality View." University of Maryland.

Magud, N., C. Reinhart, and K. Rogoff. 2011. "Capital Controls: Myth and Reality-A Portfolio Balance Approach.” Working Paper 11-7. Washington: Peterson Institute of International Economics.

Ostry, J. , A.Ghosh, K. Habermeier, M. Chamon, M.Qureshi, and D. Reinhardt. 2010. "Capital Inflows: The Role of Controls." Staff Position Note 10/04. Washington: International Monetary Fund. 
Ostry, J. , A.Ghosh, K. Habermeier, L. Laeven, M. Chamon, M.Qureshi, and A. Kokenyne. 2011. "Managing Capital Inflows: What Tools to Use?" Staff Discussion Note 11/06. Washington: International Monetary Fund.

Prasad, E., K. Rogoff, S.J. Wei, and M.A. Kose. 2003. "Effects of Financial Globalization on Developing Countries: Some Empirical Evidence." Occasional Paper 220. Washington: International Monetary Fund.

Raddatz, C. and S. Schmukler. 2011. "On the International Transmission of Shocks: Micro-Evidence from Mutual Fund Portfolios.” Working Paper 17358. Cambridge, Mass.: National Bureau of Economic Research.

Rajan, R. 2010. "Beggaring the World Economy." New York: Project Syndicate. Available online at www.project-syndicate.org/ commentary/beggaring-the-world-economy.

Schindler, M. 2009. "Measuring Financial Integration: A New Dataset," IMF Staff Papers 56(1): 222-38. 